\title{
NATURE AND ORIGINS OF VALUE ADDED TAX
}

\author{
KPE Lasok QC
}

\section{A. INTRODUCTION}

B. THE NATURE OF VAT

1. The common system of VAT

2. The application to goods and services of a general tax

3. A general tax on consumption

4. A tax exactly proportional to the price of the goods and services, however many transactions take place in the production and distribution process before the stage at which the tax is charged

5. The stage at which the tax is charged

6. On each transaction, VAT, calculated on the price of the goods or services at the rate applicable to such goods or services, shall be chargeable after deduction of the amount of VAT borne directly by the various cost components

7. Transactions

(a) Taxable transactions $\quad 1.16$

(b) Exempt transactions $\quad 1.17$

(c) Exemption with deductibility (or refund) of tax or zero-rating $\quad 1.18$

(d) Non-supplies $\quad 1.19$

8. Transaction chains $\quad 1.20$

C. THE PROHIBITION OF DOMESTIC TURNOVER TAXES

D. THE ORIGINS AND DEVELOPMENT OF VAT

\section{A. INTRODUCTION}

1.01 Value Added Tax (VAT) is the name given to a particular type of indirect tax $^{1}$ that, in one form or another, has become prevalent around the

1 An indirect tax is usually said to be a tax imposed on goods and services; whereas a direct tax is a tax imposed on persons. However, all taxes are owed and paid by persons in one way or another. In one sense, a tax is 'direct' because it applies to the person required to pay it by reference to factors peculiar to that person (e.g., his income); a tax is 'indirect' because it applies to the person required to pay the tax by reference to factors extraneous to that person. John Stuart Mill put the matter in a more conventional way as follows in his Principles of Political Economy (ed. J.L. Laughlin, 1885): 'A direct tax is one which is demanded from the very persons who, it is intended or desired, should pay it. Indirect taxes are those which are demanded from one person in the expectation and intention that he shall indemnify himself at the expense of another: such as the excise or customs. The producer or exporter of a commodity is called upon to pay tax on it, not with the intention to levy a peculiar contribution upon him, but to tax through him the consumers of the commodity, from whom it is supposed that he will recover the amount by means of an advance in price' (see Book V, Chapter II, para. 1). There is surprisingly little guidance in the EU cases on the difference between a direct and an indirect tax. For one case, see Aer Lingus v Commission (Case T-473/12), 5 February 2015, para. 89 (and see also para. 113). 
world. ${ }^{2}$ The topic of this book is the variant of VAT applied in the Member States of the European Union (the EU). That variant is identical in its basic elements and a large amount of its detail in all the Member States of the EU. ${ }^{3}$ All the Member States of the EU employ the same form of VAT because the EU is based upon a common market (also known as a single, or internal, market) between its members and, in order to eliminate fiscal distortions of trade in goods and services between the Member States, it was decided that each Member State should adopt the same method of taxing goods and services. ${ }^{4}$ That policy decision is manifested in:

(i) a prohibition on the use by the Member States of 'turnover taxes'; 5

(ii) an obligation binding Member States to employ VAT; and

(iii) an obligation binding them to adjust their domestic VAT legislation so as to conform to the system of VAT laid down in legislation adopted by the EU institutions. ${ }^{6}$

2 'Over the last few decades, VAT has swept the world': Richard M. Bird and Pierre-Pascal Gendron, VAT Revisited: a new look at the value added tax in developing and transitional countries (2005). A.J. Easson, Taxation in the European Community (Athlone, 1993) refers to a number of works dealing with the theoretical background to VAT in Ch. 3 (in particular, fn 52). Value Added Tax: a study of methods of taxing financial and insurance services, a study carried out by Ernst and Young (Canada) for the European Commission, provides an interesting insight into the application of VAT to financial and insurance services.

3 The European Union was created by the Treaty on European Union (signed at Maastricht in 1992 and often known as 'the Maastricht Treaty' but here referred to as 'the TEU'). Art. 1 provided that the EU is 'founded on the European Communities'. By the Reform Treaty (signed at Lisbon in 2007 and therefore known as 'the Lisbon Treaty'), which entered into force on 1 December 2009, the TEU was amended significantly and the reference to 'the European Communities' was removed. The EU is now founded on the TEU, as amended, and on the Treaty on the Functioning of the European Union ('the TFEU'), which is a much amended version of the Treaty establishing the European Community (signed at Rome in 1957 and usually known as 'the EC Treaty'). VAT is derived from provisions of the TFEU (an up-to-date version of which is published in the Official Journal of the EU and available electronically from the EU website). The Lisbon Treaty not only retitled the EC Treaty (as the TFEU) but also renumbered its provisions. The terms 'EU', 'European Union' and 'EU law' have now replaced the terms 'EC', 'European Community' and 'EC law'. In the VAT context, the word 'Community' is still used (as in the expression 'intra-Community acquisition', where it refers to a transaction taking place within the EU and between two Member States of the EU). Before the appearance of 'EU law' as a result of the TFEU and the Lisbon Treaty, most references in the cases and commentaries were to 'EC law' or 'Community law'). The UK ceased to be a Member State of the EU with effect from the end of January 2020 but EU law continues to apply in the UK during a transition period (see further Ch. 3).

4 Council Directive 2006/112 ([2006] OJ L347/1- 'the VAT Directive') recital 4, which harks back to Council Directive 67/227 ([1967] OJ L71/1301; Eng. Sp. Ed. 1967 p. 14), also known as 'the First VAT Directive'. See also cases such as Bergandi v Directeur-general des impots (252/86) [1988] E.C.R. 1343 para. 7 of the judgment.

5 Currently to be found in the VAT Directive Art. 401.

6 The two obligations referred to in the text were originally set out in Council Directive 67/228 ([1967] OJ L71/1301; Eng. Sp. Ed. 1967 p. 16) Art. 1, also known as 'the Second VAT Directive'. EU VAT legislation is adopted under what is now TFEU Art. 113 and originates in proposals drawn up by the Commission of the European Communities, or European Commission ('the Commission'), the EU's executive. That legislation is adopted by the Council, which consists of representatives of the governments of the Member States. The European Parliament (which consists of elected representatives of the peoples of the Member States) and the Economic and Social Committee (which consists of appointed representatives of the 
The EU VAT legislation is known as 'harmonising' legislation because its function is to define standard rules to which the legislation of the Member States is to conform, thereby bringing the legislation of all the Member States into line with each other. ${ }^{7}$ This chapter deals first with an exploration of the features of the VAT system, including the related prohibition on different forms of turnover tax. It then deals with the origins of VAT and its development over the years in the EU, which may in particular assist in an understanding of the context of the VAT system and in a reading of the case law (when the case law refers to legislation that has now been replaced). The important but complex topic of the relationship between EU and domestic VAT legislation is considered in Chapter 2.

\section{B. THE NATURE OF VAT}

1.02 The basic features of the VAT system, as applied throughout the EU, are defined in EU legislation as follows:

The principle of the common system of VAT entails the application to goods and services of a general tax on consumption exactly proportional to the price of the goods and services, however many transactions take place in the production and distribution process before the stage at which the tax is charged.

On each transaction, VAT, calculated on the price of the goods or services at the rate applicable to such goods or services, shall be chargeable after deduction of the amount of VAT borne directly by the various cost components.

The common system of VAT shall be applied up to and including the retail trade stage. $^{8}$

1.03 Before picking apart the different features of VAT that emerge from that description, the general picture given by it is of a tax that is applied to (or at the point of) the transactions in goods and services that occur from time to time as from the stage of production (or, in the case of services, if one likes,

different economic and social components of organised civil society—industry, consumers and so forth) play a consultative and advisory role in the adoption of VAT legislation: see Art. 113 TFEU. The judicial institution of the EU is the Court of Justice of the European Union which, at the time of writing, comprises two courts: the Court of Justice ('the ECJ') and the General Court ('GC'), formerly known as the Court of First Instance of the European Communities. Due to the division of jurisdiction between the ECJ and the GC, VAT cases referred by domestic courts and tribunals are heard by the former not the latter.

7 The degree of 'harmonising' required is determined by the terms of the 'harmonising' provisions themselves. They may require only a limited degree of convergence between the laws of the Member States or provide for a single, definitive, norm from which the Member States are not to diverge. In the case of VAT, harmonisation is partial, not complete.

8 VAT Directive Art. 1(2), which replicates the First VAT Directive Art. 2. 
generation) to the stage of supply by retail. The tax is exactly proportional to the price of the goods or services in question charged at the time of the transaction in question and does not vary by reference to the greater or lesser number of (taxed) transactions that may have taken place beforehand. However, at each transaction stage, the tax is 'chargeable' after deduction of the amount of tax that has already been charged in respect of earlier transactions. When the chain of transactions comes to an end, the accumulated financial burden of the tax rests with the person at the end of the chain. In that system, only the final consumer of the goods or services (the person at the end of the chain) is, in principle, taxed. The suppliers of goods and services at different points in the chain of supply leading to the final consumer act as tax collectors on behalf of the tax authorities. In that capacity, they charge the appropriate amount of tax to the purchasers from them and account to the tax authorities for the appropriate amount due at that point in the chain. ${ }^{9}$ The actors in the chain of supply before the final consumer at the end of it are referred to in the EU legislation as 'taxable persons'. That is not a description of their role in the system (which is rather that of a tax collector) but a designation of their status in the system as persons who carry out transactions subject to the tax. ${ }^{10}$

9 Elida Gibbs Ltd v Commissioners of Customs and Excise (C-317/94) [1996] E.C.R. I-5339 paras 19 and 22 of the judgment. Although para. 19 states that 'the basic principle of the VAT system is that it is intended to tax only the final consumer', VAT is actually an indirect tax and, therefore, supplies of goods and services (not persons) are taxed. It would be technically more accurate to say that the basic principle of VAT is that it is intended that the fiscal burden of the tax shall fall only on the final consumer. See also Balocchi v Ministero delle Finanze (C-10/92) [1993] E.C.R. I-5105, para 25 and Netto Supermarkt GmbH E Co OHG v Finanzamt Malchin (C-271/06) [2008] E.C.R. I-771 para. 21 of the judgment.

10 Readers will be aware of how the system works. For those who may not, suppose that a manufacturer (A) produces and sells a particular product to a wholesaler (B) at a price of 100 (excluding VAT). B sells to a retailer (C) at a price of 250 (excluding VAT). C sells to a final consumer (D) at a price of 300 (excluding VAT). Assume also that the rate of VAT is $10 \%$. It follows that A sells to B at a price of 100 plus VAT of 10. A receives a total of 110 from $B$ and pays 10 to the tax authorities. When $B$ sells the product to $C, B$ charges $\mathrm{C}$ the purchase price of 250 plus VAT of 25 . B receives 275 from $\mathrm{C}$ and accounts to the tax authorities for the difference between the VAT already paid by B to A (10) and the 25 charged to, and received from, C (25). B therefore pays 15 to the tax authorities. When $\mathrm{C}$ sells to $\mathrm{D}$, the price of the product is 300 plus VAT of 30 . C receives 330 from D. C has already paid B 25 by way of VAT and therefore accounts to the tax authorities for the difference between 25 and $30 . \mathrm{D}$, the final consumer, does not resell the product in the way of business and so does not charge VAT to anyone. At all stages, the VAT charged to the next person in the chain of supply is exactly proportional to the price of the product. $\mathrm{D}$ ends up paying 30 (10 per cent of 300) by way of VAT. Exactly the same amount has been received by the tax authorities in the aggregate from A, B and C. That example is, of course, simplistic, not least because it assumes that: (i) in order to manufacture the product in question, A has not bought any goods or services on which VAT had to be paid - any such purchases would have given A an entitlement to deduct, from the 10 charged by $A$ to $B$ by way of VAT, the VAT paid on acquisition of the goods or services used in the manufacture of the product; and (ii) A, B and C are engaged solely in selling (or, in the case of B and C, reselling) the product whereas it might in fact be acquired for incorporation into another product or may be consumed in the making of another product or in the supply of a service. In VAT parlance, a business' acquisitions for business purposes are usually described as its 'inputs'. Its supplies are described as 'outputs'. 
1.04 Accordingly, the financial burden of the tax falls in principle on the final consumer-the person at the end of the chain of transactions running from production to the retail stage. The final consumer pays an amount calculated solely by reference to the price charged to him or her for the goods or services in question. The tax so raised is actually paid over to the tax authorities (by the 'taxable persons') in instalments by reference to each point at which there is a transaction involving the supply of the goods or services in question between their production (or generation) and the retail stage and therefore before the goods or services reach the final consumer. ${ }^{11}$ At each of those points, although an instalment of the tax is to be accounted for to the tax authorities, the financial burden of the tax is, in principle, passed on down to the next person in the chain of supply until it comes to rest with the final consumer. ${ }^{12}$ The instalments paid over to the tax authorities equal in the aggregate the amount of VAT paid by the final consumer.

1.05 Viewed in that way, VAT can be said to have four salient features:

(i) it is a transaction-based tax;

(ii) it is oriented around the concept of a chain of supply running (in principle) from production to final consumption;

(iii) the charge to tax is proportional to the price of the goods or services supplied and otherwise unvarying; ${ }^{13}$ and

(iv) VAT uses a deduction mechanism at each stage before final consumption so as to pass on the burden of the tax down the chain and prevent the total amount raised from exceeding the appropriate proportion of the price of the goods and services supplied. ${ }^{14}$

To those features of VAT, viewed as a tax, may be added four particular features of the VAT system:

11 Taxable persons pay the VAT collected by them to the tax authorities by reference to accounting periods. They do not make a payment each and every time there is a taxed transaction.

12 Although the tax is organised so that the financial burden is passed down the chain of transactions to the final consumer, the VAT system does not guarantee that that result ensues in real terms. The tax is perfectly capable of affecting demand for particular goods or services and may therefore cause taxable persons to reduce their profit margins (in order to avoid an effect on demand) even though they can in principle pass the tax on to the next person in the chain. The passing of the financial burden of the tax down the chain until it rests with the final consumer is therefore best regarded as a technical feature of the operation of the tax rather than as an economic function of the tax. Hence, when in cases like Commission v Germany (427/98) [2002] E.C.R. I-8315 para. 73 of the judgment, the ECJ says 'because VAT is neutral it does not, in principle, constitute a cost factor', the emphasis should be on the phrase 'in principle' (that is, in theory). Similarly, when a business promotes the sale of a (taxed) product by saying that a customer can purchase it 'VAT-free', the true meaning of the statement is that the seller has decided to reduce its profit margin by the amount of the VAT to be paid in respect of the sale.

13 See Ch. 7.

14 See Ch. 11. 
(i) the arrangements for dealing with the situation that arises when goods or services enter or pass out of the fiscal jurisdiction; ${ }^{15}$

(ii) the exemptions from tax; ${ }^{16}$

(iii) the concept of what is known as exemption with deductibility (or refund) of the tax previously paid, or zero-rating; ${ }^{17}$ and

(iv) the phenomenon of activities or transactions that fall entirely outside the scope of VAT. ${ }^{18}$

Those different features will be discussed briefly below and more detailed treatment of them is to be found in later chapters.

\section{The common system of VAT}

The common system of VAT comprises the rules adopted by the EU institutions to harmonise the national legislation of the Member States in relation to VAT. Historically, the common system developed in stages. ${ }^{19}$ At each stage, the degree to which VAT law was the subject of harmonisation increased. However, three points need to be borne in mind about the common system. First, it is not complete. ${ }^{20}$ Secondly, where there are gaps in the common system, it does not follow that there is no relevant legal provision. It just means that each Member State is free to determine what kind of legal provision is needed in order to fill the gap. ${ }^{21}$ Thirdly, the expression 'common system' of VAT does not mean a 'common' tax. The EU institutions do not have general tax-raising powers and, more particularly, have no power to impose indirect taxes. VAT is a domestic tax of each Member State of the EU. It is not an EU tax. The common system is intended to render uniform throughout the EU the operation of a particular type of domestic tax. That does not transform the tax into an EU tax; and it does not mean that the different fiscal jurisdictions of the Member States have ceased to exist.

\footnotetext{
See Chs 12 and 14.

See Ch. 10.

See para. 1.18 below.

See para. 1.19 below.

See further paras 1.25 and following below.

20 E.g., Administration de l'enregistrement et des domains v Eurodental Sarl (C-240/05) [2006] E.C.R. I-11479 para. 50 of the judgment.

21 The freedom of Member States to fill gaps left in the common system is, however, constrained by the need to avoid interfering with the operation of the common system. Thus, in Garage Molenheide $v$ Belgium (C-286/94, C-340/95, C-401/95 and C-47/96) [1997] E.C.R. I-7281, the domestic provisions in question concerned matters that had not been the subject of harmonisation. The ECJ held that Member States could act as they wished but could not act in such a way as to undermine fundamentally the operation of provisions of the harmonised system. Otherwise, the domestic provisions could interfere with the operation of the harmonised system as long as they were proportionate (as to the principle of proportionality, see Ch. 2 para. 2.72, below).
} 


\section{The application to goods and services of a general tax}

1.07 VAT is intended to apply generally to supplies of goods and services. It is not a sectoral tax applied only to particular goods or services; and it is not a tax that is applied to persons. In general terms, 'goods' and 'services' are defined broadly so that the tax applies as widely as possible to economic activities involving supplies of value from one person to another for reward. Certain economic phenomena are not subject to the tax. ${ }^{22}$ Otherwise, express provision is required for the supply of something that is characterisable as goods or a service to be excluded ('exempt') from the charge to tax. Thus, the fact that a supply of goods or services is unlawful for some reason does not exclude the supply from the scope of the tax because VAT does not treat lawful and unlawful transactions differently. The position is otherwise where the purpose and effect of rendering the supply unlawful is to prevent the goods or services in question from being released into economic and commercial channels within the EU so that there can be no competition between an unlawful economic sector and a lawful one. In that event, the unlawful supply does not fall within the class of transactions subject to VAT. ${ }^{23}$ For the same reasons, where the constituent elements of a supply of goods or services take place, the transaction is subject to VAT even though it may be void, as a matter of civil law, because it has been used as the vehicle for fraud. ${ }^{24}$ The distinction

22 E.g., Hutchison $3 G$ UK Ltd v Commissioners of Customs and Excise (C-369/04) [2007] E.C.R. I-5247 (grant by a Member State of licences to use the electromagnetic spectrum); Petar Kezic s.p. Trgovina Prizma $v$ Republika Slovenija (C-331/14), 9 July 2015, para. 18 (transactions effected by a taxable person otherwise than 'as such' not subject to VAT). In relation to the situation that arose in Hutchison $3 G$, ordinary analysis would lead to the conclusion that the grant of such licences is an economic activity because, reduced to its essentials, the grant involves a buyer and a seller, a product and a price (in addition, the way in which the grant was organised-an auction - appears on the face of it to be an economic activity). However, the judgment looks at the grant of the licence as the creation of an opportunity to engage in an economic activity. That is distinct from a production activity (which is ordinarily subject to VAT): the grant of a licence to engage in an economic activity is anterior to the production stage.

23 Einberger $v$ Haupzollamt Freiburg (294/82) [1984] E.C.R. 1177 (importation of illegal drugs into the EU not subject to VAT); Mol v Inspecteur der Inveorrechten en Accijnzen (269/86) [1988] E.C.R. 3627 (see, in particular, paras 18-19-unlawful supply of illegal drugs not subject to VAT); Vereniging Happy Family Rustenburgerstraat $v$ Inspecteur der Omzetbelasting (289/86) [1988] E.C.R. 3655 (see, in particular, paras 20-21 and 29-31 of the judgment - unlawful supply of illegal drugs within a Member State not subject to VAT even if the prosecution authorities tolerate small-scale dealing); Witzemann v Hauptzollamt MunchenMitte (C-343/89) [1990] E.C.R. I-4477 (supplies of counterfeit currency not subject to VAT); Lange v Finanzamt Fürstenfeldbruck (C-111/92) [1993] E.C.R. I-4677 (VAT applicable to an unlawful export transaction because the nature of the illegality was not such that the goods in question were wholly excluded from commercial channels); Criminal proceedings against Goodwin and Unstead (C-3/97) [1998] E.C.R. I-3257 (supplies of counterfeit perfume subject to VAT); Fischer v Finanzamt Donaueschingen (C-283/95) [1998] E.C.R. I-3369 (unlawful games of chance subject to VAT); Staatsecretaris van Financien v Coffeeshop 'Siberie' (C-158/98) [1999] E.C.R. I-3971 (the unlawful supply of accommodation for the purpose of selling illegal substances subject to VAT); Tullihallitus v Kaupo Salumets (C-455/98) [2000] E.C.R. I-4993 (contraband imports of alcohol subject to VAT).

24 Kittel v Belgium (C-439/04 and C-440/04) [2006] E.C.R. I-6161 para. 52 of the judgment. 
between unlawful (or void) activities that are subject to VAT and those that are not can be easy to state but elusive to apply. The cases that are easy to pigeon-hole are those where a transaction falls into a category of unlawful activity because of some accident or feature of the transaction but not because of the essential nature of the transaction (an example is the carrying out of a transaction that is intrinsically lawful but the supplier lacks a permit or authorisation enabling him to carry out the transaction lawfully). In such cases, the unlawful character of the transaction does not take it outside the scope of VAT. ${ }^{25}$ In other cases, in which the reason for the illegal nature of the transaction appears to lie in the very nature of the transaction, rather than some accessory feature of it, that reason still needs to be explored before it can safely be concluded that the transaction is outside the scope of VAT. In general terms, in order for the transaction to be outside the scope of VAT, the purpose of rendering it unlawful (or void) must be to suppress the type or class of transaction to which the transaction in question belongs. Where the purpose is merely to control or discourage it, the transaction would appear to be within the scope of VAT. ${ }^{26}$

\section{A general tax on consumption}

VAT is, by virtue of its title, a tax on value added. ${ }^{27}$ The legislative description of the tax describes it as a general tax on consumption. ${ }^{28}$ Elsewhere, it is also assimilated to a turnover tax. ${ }^{29}$ Each of those descriptions has something to be said for it and something against. ${ }^{30}$ Thus, VAT can be described as a tax on value added because, due to the deduction (from the tax charged at a particular transaction stage) of the tax collected at earlier transaction stages, the effective tax charge (the amount accounted for by a supplier to the tax authorities)

25 Two qualifications need to be made to that statement. First, if the lawful variant of the transaction is itself outside the scope of VAT (as in the example provided by the Hutchison $3 G$ case, fn 22 above), a defect in the transaction that renders it unlawful does not bring the transaction within the scope of VAT. Secondly, while the lawful and unlawful variants of a transaction may fall within the scope of VAT, it does not necessarily follow that they receive the same fiscal treatment. For example, where an exemption applies to a transaction carried out by an authorised person, the same type of transaction, when carried out (unlawfully) by an unauthorised person, may not be exempt but taxed. Where that occurs, the crucial point is not, however, the legality or illegality of the transaction but the fact that it does not feature all the characteristics required for it to fall within the exemption.

26 For example, if national law exposes a prostitute's client to prosecution for a criminal offence but does not otherwise affect the transaction, the implication is that national law intends only to show disapproval of prostitution and, by sanctioning the client, seeks to suppress demand, but does not go further.

27 That is, e.g., the French language version of what, in English, is expressed by the phrase 'value added tax'.

28 VAT Directive Art. 1(2).

29 VAT Directive recitals (1), (2) and (4). The Second Directive Art. 1, expressly referred to VAT as a tax on turnover.

30 For a lengthier discussion of the question, see Ben Terra and Julie Kajus, $A$ Guide to the European VAT Directives, Ch. 9. 
reflects any increase in the price paid by the purchaser to the supplier over the price paid by the latter on acquisition of the goods or services in question for onward supply. The implication is that the increase in price results from an addition of value made by the supplier. ${ }^{31}$ However, in some instances, any increase in price reflects movements in market prices rather than the addition of any value (gold held for investment is an example). ${ }^{32}$ Further, the function of the deduction mechanism, which is usually said to be to ensure that taxable persons are not improperly charged tax, ${ }^{33}$ has the consequence of passing on the financial burden of the tax to the next person in the chain so that it does not fall on the value added. Therefore, the 'value added' basis of the tax really refers to its method of collection, not to the underlying rationale for the tax. To describe VAT as a tax on consumption seems to be more accurate as long as 'consumption' means 'final consumption' and some care is taken about what exactly 'consumption' is taken to mean. For example, if a manufacturer of bicycles engages a firm to clean the manufacturer's premises, the manufacturer consumes the cleaning firm's services which do not, in any obvious way, find themselves incorporated into the bicycles sold by the manufacturer and bought and used or consumed, ultimately, by the final consumer. Nonetheless, the manufacturer is entitled to deduct the VAT charged by the cleaning firm from the VAT paid by the purchaser of the bicycles, thus passing the burden of the VAT on down the chain of supply of the bicycles. The final consumers (the ultimate purchasers and users of the bicycles) end up bearing the financial burden of the VAT on the cleaning firm's services even though the final consumers do not, in any real or physical sense, consume those services. Further, in the VAT system, some persons stand in for, or are assimilated to, the final consumer even though they do not actually consume the goods or services in question, because they find themselves at the end of the VAT chain. ${ }^{34}$ Moreover, for a tax on consumption, the common system of VAT is

31 E.g., Forvaltings AB Stenholmen v Riksskatteverket (C-320/02) [2004] E.C.R. I-3509 para. 27 of the judgment. In practice, the value added is inferred from the disparity between (i) the VAT on the inputs used by the taxable person when carrying on the business of making taxable supplies; and (ii) the VAT on those taxable supplies. There is no calculation of the price or value of the inputs themselves for the purpose of determining the extent of the value added. Further, VAT is still applied where the price (and, hence, the perceived value) of the taxable person's (taxable) outputs is less than the price (or value) of his inputs (which may occur where, for example, there is a downturn in the market or some other reason why a taxable person sells at a loss). In that event, it may be said, no value is added (viewed in terms of price). Even though the tax is still charged on the output, it would in that event be less than the tax borne by the taxable person on his inputs and the difference would be repaid to him.

32 That can be explained by saying that 'value added' refers to any increase in value manifested in a price increase irrespective of the reason for it.

33 Elida Gibbs (above) para. 23 of the judgment.

34 E.g., a person whose activity consists exclusively in providing services for no consideration: Staatsecretaris van Financien v Hong Kong Trade Development Council (89/81) [1982] E.C.R. 1277 paras 9-10 of the judgment. Not all supplies made without consideration (in the conventional sense) are, however, outside the scope of VAT: see further Ch. 5 . 
rather odd because the place of supply rules (which determine where a supply is to be taxed) do not generally refer to the place of consumption. ${ }^{35}$ Finally, the description of VAT as a turnover tax is not really consistent either with the idea of VAT as a tax on consumption or with the idea of VAT as a tax on value added. Turnover has been taken to mean what a person receives in exchange for his outputs. ${ }^{36}$ That shifts attention away from consumption. It is also different from the value added by a person at a given transaction stage (which, for the sake of completeness, is also different from the profit made). Since the real taxpayer is the final consumer (who, effectively by definition, has no turnover) and other persons in the chain of supply are tax collectors, the idea of VAT as a turnover tax, in the literal sense, is not entirely comfortable. ${ }^{37}$

At face value, the different expressions, 'tax on value added', 'tax on consumption' and 'turnover tax', are approximate but not adequate descriptions of VAT: each reflects a particular aspect, but not the whole character, of the tax. It is a turnover tax in two senses:

(i) it replaces turnover taxes in the Member States; 38 and

(ii) the taxable amount is a person's 'turnover' (in the sense of what that person receives in exchange for a supply of goods or services).

VAT is a tax on value added in the sense that the mechanism for deducting tax paid in respect of previous transactions reduces the amount of tax that must be accounted for at any one transaction stage to an amount that reflects any increase in price at that stage. VAT is a tax on (final) consumption in the sense that it is designed so that the financial burden of the tax is passed on to the final consumer; and, if consumption does not take place within the fiscal jurisdiction, VAT does not in principle apply. ${ }^{39}$

35 VAT Directive Arts 31-61. See Ch. 6. That peculiarity of the place of supply rules is occasionally explained away by saying that the place of origin (or supply) stands as a proxy for the place of destination (or consumption) for reasons of administrative simplicity or ease of collecting the tax.

36 Advocate General Jacobs in H.J.Glawe Spiel-und Unterhaltungsgerate Aufstellungsgesellschaft mbH and Co KG v Finanzamt Hamburg-Barmbek-Uhlenhorst (C-38/93) [1994] E.C.R. I-1679 para. 18 (p. 1686).

37 For further consideration of the meaning of 'turnover tax' see para. 1.23 below.

38 VAT Directive Art. 401; Second Directive Art. 1.

39 See, e.g., Lange v Finanzamt Fürstenfeldbruck (above) para. 20 of the judgment ('the intention is that [VAT] should be borne exclusively by consumers within the Community'). 
4. A tax exactly proportional to the price of the goods and services, however many transactions take place in the production and distribution process before the stage at which the tax is charged

1.10 The tax is levied by reference to the price of what is supplied, not by reference to some other factor, such as its value, whether actual or assumed. ${ }^{40}$ The proportionality of the tax to the price of the goods or services supplied refers to two things:

(i) the fact that the tax rate is expressed as a percentage of the price of the goods or services; and

(ii) the tax in principle maintains the same proportionate relationship to the price of the goods or services irrespective of the number of transactions that take place in the chain of transactions leading from production to consumption.

It was an important purpose of the common system of VAT that the proportion borne by the tax by reference to the price of the goods or services supplied should not vary by reference to the number of transactions in the chain for two main reasons. First, if the tax was applied cumulatively to the supply of goods or services at each transaction stage, the tax burden would increase progressively; and that would lead to difficulties in determining the correct amount of tax to impose in respect of goods or services supplied from one fiscal jurisdiction to another within the EU. Secondly, if the tax burden altered by reference to the number of transactions in the chain, that could distort competition and business structures because it would introduce an artificial fiscal incentive for businesses to be vertically integrated, thus reducing the number of transactions in the chain. The levying of the tax by reference to the price of a transaction has as its corollary that a transaction escapes the charge to tax if it does not have a price. ${ }^{41}$

40 There are, however, exceptional situations in which the taxable amount may not be the price: see Ch. 8.

41 Staatsecretaris van Financien v Hong Kong Trade Development Council (above) paras 10-13 of the judgment. In some instances, however, express provision is made that transactions without a price may be taxable: see further Ch. 5 . 


\section{The stage at which the tax is charged}

VAT is said to be 'chargeable' on each transaction (after deduction of input tax). ${ }^{42}$ That appears to be inconsistent with the idea of the tax being proportionate to the price of the goods or services, however many the transactions taking place in the production and distribution process 'before the stage at which the tax is charged'. ${ }^{43}$ In practice, VAT is in principle 'charged' when a 'chargeable event' occurs (although particular provisions may separate the chargeable event from the point at which VAT is chargeable). ${ }^{44}$ Chargeable events usually, but not always, coincide with a 'transaction', in the ordinary sense in which that word is used. The charge to tax (in the sense of the levy of the tax on a party to a transaction) commonly manifests itself in the issue by the supplier of an invoice that identifies the VAT to be paid in respect of the supply. The VAT is paid to the supplier who accounts for it to the tax authorities. Viewed in that way, it appears to make little sense to refer to the number of transactions taking place 'before the stage at which the tax is charged'. However, the language used in the EU legislation is in that respect somewhat elliptical; and some care needs to be exercised when the word 'charge' and its variants are encountered. ${ }^{45}$ As noted above, the role of taxable persons in the VAT system is to act as tax collectors. Instead of the tax being collected from the final consumer and paid over to the tax authorities when the chain from production to consumption has come to an end, it is collected by the taxable persons participating in the chain and accounted for by them to the tax authorities in stages. ${ }^{46}$ In order for that to happen, the tax has to be 'chargeable' (or, to put it another way, leviable) on each transaction in the chain because, if it were not 'chargeable', it would not be collectible. 'The stage at which the tax is charged' is therefore really the point at which the tax burden comes to a rest rather than the point at which the tax is levied. That has two important consequences. First, it means that, in principle, the aggregate amount collected by way of tax (after deduction of input tax) may not exceed the amount obtained by applying the appropriate rate of tax to the

42 VAT Directive Art. 1(2) 2nd subpara. The observation that VAT is in principle payable only after the event (see Balocchi v Ministero delle Finanze (C-10/92) [1993] E.C.R. I-5105, para. 20 of the judgment) reflects the fact that, subject to express provision otherwise, the transaction must occur and the supply take place for VAT to apply.

43 VAT Directive Art. 1(2) 1st subpara.

44 See Ch. 7.

45 VAT is 'chargeable' when the tax authority becomes legally entitled to claim it, not when a taxable person is entitled to claim it from a customer: see VAT Directive Art. 62(2). Further, the concept of chargeability of VAT is distinct from that of payment of VAT to the tax authorities: see Balocchi (above) para. 24 of the judgment (p. 5140). In the VAT Directive Art. 1(2), 2nd subpara, 'chargeable' appears to have the same meaning as it bears in Art. 62(2); but that is not the same meaning that the verb 'charge' has in Art. 1(2) 1st subpara.

46 That factor renders the tax attractive to tax authorities for cash flow reasons. 
sum paid by the (final) consumer for the goods or services in question. ${ }^{47}$ Secondly, as the tax burden comes to a rest in principle at the point of (final) consumption, arrangements have to be made for the situation that arises when that point is outside the fiscal jurisdiction within which transactions preceding the consumption stage have taken place. When goods or services pass from one fiscal jurisdiction to another before the consumption stage has been reached, the VAT chain is broken. That is so whether the two jurisdictions in question are both within the scope of the harmonised system of VAT (such as where goods pass from one Member State of the EU to another) or one jurisdiction is within it and the other is not (such as where goods are exported from a Member State to a country outside the EU). In both cases, VAT will have been accounted for in a Member State; but that State is not the fiscal jurisdiction within which the consumption stage is reached. For that reason, the VAT accounted for in that jurisdiction is in principle to be reimbursed to the taxable persons who accounted for it. ${ }^{48}$ If the goods or services in question are received in another Member State, the VAT chain restarts in that State. If the goods or services are exported to a country outside the EU, they cease to be subject to the harmonised system of VAT.

\section{On each transaction, VAT, calculated on the price of the goods or services at the rate applicable to such goods or services, shall be chargeable after deduction of the amount of VAT borne directly by the various cost components}

1.12 The word 'chargeable' here refers to the obligation of a taxable person to account for VAT and to the correlative right of the tax authorities to claim VAT from that person. ${ }^{49} \mathrm{~A}$ fundamental aspect of VAT is that taxable persons are obliged to account for and pay only the output tax charged by them to their customers less the VAT borne directly by the various cost components of their output transactions. Deduction is, accordingly, an integral part of the mechanism for determining the amount of tax to be paid over to the tax authorities by a taxable person. The charging of VAT (understood in that

47 Elida Gibbs (above) paras 19 and 24 of the judgment.

48 Under the VAT system, taxable persons are (in principle) able to pass the burden of VAT down to the next person in the chain of transactions. Hence, the VAT that has accumulated in the chain is borne by the last person in the chain within the fiscal jurisdiction. In order to strip the VAT out of the chain when the goods or services pass out of the fiscal jurisdiction before the consumption stage, it is sufficient to return to the last taxable person in the chain the amount of VAT that he has paid to the taxable person who supplied him with the goods or services in question. The arrangements for dealing with chains of transactions that lead to consumption outside the fiscal jurisdiction are, however, rather complex and the text above does not attempt to do more than summarise what the position, in principle, is in the absence of express provision otherwise.

49 See VAT Directive Art. 62(2). As noted in fn 45 to para. 1.11 above, the right of the tax authorities to claim VAT from a taxable person is distinct from the latter's right to obtain payment of VAT from a customer. 
sense) on each transaction after deduction of the VAT borne directly by the cost components of that transaction is not a mere theoretical consideration. It means that VAT is applied on a transaction basis and not, for example, to a taxable person's overall turnover. From the perspective of the deduction of input tax, it means that, in principle, input tax is deductible to the extent that it is referrable to a particular taxable supply. ${ }^{50}$ VAT did not have to be designed in that way. In principle, a value added tax such as VAT could use either what is known as the 'subtraction method' or what is known as 'the tax credit' or 'invoice method' for its collection. The subtraction method is the simplest and requires the taxable person to calculate the amount of tax to be accounted for to the tax authorities by deducting purchases from sales and applying the tax rate to the difference. ${ }^{51}$ The tax credit or invoice method, which is the one adopted in the EU legislation, is, in principle, transaction based and works by deducting the tax incurred in respect of the inputs used by the taxable person for the purpose of making a particular supply, or output, from the tax charged on that output. ${ }^{52}$ For the purpose of accounting for the tax to the domestic tax authorities, the results derived from each transaction in a given accounting period are aggregated; but that does not alter the transaction-based nature of the method. That method was selected for the EU harmonised system because of the particular features of the EU system and, more particularly, the fact that it was devised to solve specific problems concerning transactions between EU Member States: where (as in the EU system) certain classes of transaction have different tax treatment either because they are exempt or because the tax system uses a variety of different tax rates, and where (as in the EU system) the tax is applied across a number of fiscal jurisdictions with the objective of ensuring that transactions between those jurisdictions are given equivalent fiscal treatment to transactions effected solely within one of those jurisdictions, the subtraction method poses serious

50 Hence the frequent references in the case law to the effect that 'the deduction of input taxes is linked to the collection of output taxes' (e.g., Hausgemeinschaft Jorg und Stephanie Wollny v Finanzamt Landshut (C-72/05) [2006] E.C.R. I-8297 para. 20 of the judgment). However, it should be noted that there are some exceptional cases in which input tax is deductible even if the input is not used in the making of a taxed supply (hence, the text above refers to 'taxable' supply). The deduction of input tax where the input is used for a supply that is not taxed must, however, be based upon an express provision to that effect: see Debouche v Inspecteur der Invoerrechten en Accijnzen (C-302/93) [1996] E.C.R. I-4495 para. 16 of the judgment (in relation to exempt outputs).

51 For the sake of clarity, the calculation is made by reference to the value of the purchases and sales but is not, strictly speaking, a tax on profit because it does not focus on other costs that should be taken into account when working out profits.

52 For a discussion of the two methods, see Tax-Credit and Subtraction Methods of Calculating a Value-Added Tax, a Report of the US General Accounting Office to the Joint Committee on Taxation, US Congress, June 1989. 
disadvantages and only a transaction based method is sufficiently attuned to the particular features of the system..$^{53}$

1.13 In order to use the tax credit or invoice method, it is necessary to allocate or attribute particular inputs to particular outputs. The basic principle of attribution is expressed in Article1(2) of the VAT Directive by reference to the "cost components' of each output transaction: only the VAT borne 'directly' by the cost components of the output transaction can be deducted from the VAT charged in respect of that output transaction. ${ }^{54}$ VAT is borne 'directly' by a cost component if it has been charged in respect of the supply of that component to the maker of the output transaction in question. ${ }^{55}$ Later in the VAT Directive, different terminology is used to describe how the basic principle of attribution is to be applied in practice. ${ }^{56}$ So far as the reference to 'cost components' is concerned, it should not be inferred that input tax is deductible from the tax chargeable on a supply only if the cost of the related input is reflected in the price of the supply. That argument was rejected in BLP Group plc v Commissioners of Customs and Excise; ${ }^{57}$ and, if accepted, would

53 Where those features exist, it is important to ensure that input tax is deducted only where that tax has been incurred in respect of inputs actually used in the making of, or attributable to, a particular (taxed) supply. For example, where a taxable person engages in the making of both taxed and exempt supplies, he cannot deduct all his input tax: if an input has been used in the making of an exempt supply, the tax on the input is not deductible. Unless a transaction-based method is used, the risk is that undeductible input tax may be deducted (whether by error or by design). Hence the chain analysis of transactions referred to in BLP Group plc v Commissioners of Customs and Excise (C-4/94) [1995] E.C.R. I-983 para. 30 of the Advocate General's Opinion (p. 993).

54 Obviously, if no VAT is charged in respect of the output transaction, deduction of input tax does not apply unless there is express provision otherwise.

55 Accordingly, what is sometimes called 'hidden' VAT is not deductible. 'Hidden' VAT is the VAT that, in economic terms, may be included in the price of a supply but does not feature as part of any charge to tax in respect of the supply. For example, the maker of an exempt supply may have purchased and consumed various taxable supplies for the purpose of making the exempt supply. Those taxable supplies are cost components of the exempt supply. However, the exempt supply is not subject to the charge to VAT. Accordingly, the maker of the exempt supply cannot pass on the VAT incurred in respect of the cost components of the exempt supply in the normal way. The price of the exempt supply will nonetheless (subject to market forces) cover the VAT borne by the maker of the exempt supply in respect of its cost components. That is the hidden VAT. If the exempt supply becomes a cost component of another person's taxable output, it follows that the economic burden of the hidden VAT will be passed on to the final consumer through the price of that taxable output. However, the hidden VAT is only 'indirectly' borne by the exempt supply because it applied to the cost components of that supply, not the exempt supply itself.

56 See further Ch. 11 below.

57 [1995] E.C.R. I-983 paras 36-37 of the Advocate General's Opinion (pp. 994-5). It is generally considered that the Advocate General's Opinion was followed by the ECJ; and it is reasonable to infer that the ECJ introduced the 'direct and immediate link' test for input tax deduction (see para. 19 of the judgment) and emphasised the need for an 'objective' link between inputs and outputs (see para. 24) precisely because it wished to exclude the possibility that input tax deduction might be claimed solely on the basis that certain costs had, for one reason or another, been incorporated into the elements forming the price of the taxed output. 


\title{
generate anomalies. ${ }^{58}$ The 'cost components' test for input tax deduction has been expressed in a variety of different ways in the case law. ${ }^{59}$ It is a way of expressing the use made of an input and not a financial test. ${ }^{60}$
}

\author{
Although VAT in respect of a transaction is chargeable after deduction of \\ input tax, what actually happens is that the VAT is charged on the transaction
}

58 E.g., if, due to a downturn in the market (or for some other reason), a taxable person was not able to sell goods or services otherwise than at a loss, some part of the cost of his inputs would not be reflected in the price of his outputs. Nonetheless, all of the inputs would have been used for the making of his (taxable) supplies and it would be contrary to the principle of the tax to limit the entitlement to deduct to the VAT on those inputs whose cost had been reflected in the price of the outputs.

59 E.g., in Commissioners of Customs and Excise v Midland Bank (C-98/98) [2000] E.C.R. I-4177, there are several references in the judgment to 'cost components of [a] transaction' (paras 21, 29, 30, 31, 32 and 33) and one reference to 'components of the price of an undertaking's products' in connexion with 'general costs' (para. 31). In Cibo Participations v Directeur regional des impots du Nord-pas-de-Calais (C-16/00) [2001] E.C.R. I-6663 para. 31 of the judgment, the ECJ refers to 'a component of the cost of those output transactions. The expenditure must therefore form part of the costs of the output transactions' (emphasis added). By comparison, in Investrand BV v Staatsecretaris van Financien (C-435/05) [2007] E.C.R. I-1315, the ECJ said in para. 23 of the judgment: 'The right to deduct VAT charged on the acquisition of input goods or services presupposes that the expenditure incurred in acquiring them was a component of the cost of the output transactions that gave rise to the right to deduct'; but, in para. 24, referred to 'components of the price of the goods or services which he supplies' (emphasis added). Needless to say, there is a difference between saying that something is a component of a cost and saying that it is a component of a price. Finally, in Eon Aset Menidjmunt OOD v Direktor na Direktsia 'Obzhalvane i upravlenie na izpalnenieto' (Case C-118/11), 16 February 2012, para. 47, the ECJ said: 'costs are part of his [the taxable person's] general costs and are, as such, components of the price of the goods or services which he supplies'. In that sense, a business cost is presumed to be a cost component of the taxable person's supplies simply because it is a business cost (it should, of course, be borne in mind that the passage quoted refers to overhead costs and is related to the taxable person's output activity viewed generally, not any particular output).

60 Inputs into a business activity are inevitably used in one way or another in order to further that activity and, unless the business is loss-making, will be financed out of the revenue received from the business activity. In that sense, all input costs are cost components of a taxable person's output transactions (viewed in their generality). As indicated in the wording of Art. 1(2), the real issue (from the perspective of input tax deduction) arises where it is necessary to attribute an input to a particular output (or class of outputs) in order to justify the deduction of input tax. Terra and Kajus in A Guide to the European VAT Directive point out (para. 12.2.2.5) that the proposal for the First VAT Directive used a form of words that indicated that inputs did not have to be direct contributions to the cost components of a taxable supply in order for the VAT on the inputs to be deductible. In their view, the finalised wording of what is now the VAT Directive Art. 1(2), was an attempt to improve on the language of the Proposal (not change its meaning) but the improvement has generated a misunderstanding of the intention of the legislator. In the ordinary course, the cost of an input can be expected to be reflected in the price of the related output. However, that cannot be regarded as an immutable rule or as the prerequisite for input tax deduction, as was recognised by the ECJ in the $B L P$ case (above), because businesses may be forced by economic or commercial imperatives to cross-subsidise different lines of business (in consequence, an input may become a cost component of one supply when it has actually been used to make another supply). It cannot be excluded that, in later cases, the ECJ has used the 'cost components' formulation too freely and without proper regard to the qualification imposed in $B L P$. Indeed, part of the problem is that the ECJ found itself dealing first with a case concerning a claim to attribute a particular business cost to a particular class of supply $(B L P)$ and only later with overhead costs. Had the cases come before the ECJ in reverse order, the various dicta in the judgments would have been clearer (it should be noted that, although a large part of the argument in $B L P$ focused on overhead costs, how they were to be dealt with in the VAT system was common ground; what was at issue was the extent to which the treatment of overhead costs shed light on the different problem of a cost component that was used for one particular output but, indirectly, for the overall benefit of the business as a whole). 
by reference to its price and accounted for to the tax authorities by the supplier after deduction of input tax. Normally, the tax charged on the transaction exceeds the input tax referable to the transaction and a net payment is due to the tax authorities. Where, as it may do for a variety of reasons, the tax charged on the transaction is less than the input tax referable to the transaction, a net payment is due from the tax authorities. In practice, a taxable person aggregates the VAT incurred in respect of all of his purchases and sales in a given prescribed accounting period in his VAT return for that period. The overall result may be an amount due to the tax authorities, a nil amount (where payments due to the tax authorities equal payments due from them) or an amount due from the tax authorities. In the first case, a payment must be made by the taxable person to the tax authorities. A taxable person who is in that situation is occasionally referred to colloquially as a 'payment trader'. In the last case, although a payment is due from the tax authorities, they may either make the payment or carry the amount due over to a later period, depending upon the circumstances. ${ }^{61} \mathrm{~A}$ taxable person who is due a payment from the tax authorities in respect of a given prescribed accounting period is occasionally referred to colloquially as a 'repayment trader'.

\section{Transactions}

1.15 The VAT system, as delineated in Article 1 of the VAT Directive, ${ }^{62}$ appears to envisage only transactions taking place in the process of producing and distributing goods and services. That is because the description given in that provision is concerned only with the general nature of VAT as a tax. The term 'transaction' is occasionally used apparently interchangeably with the term 'contract'. ${ }^{63}$ However, some care needs to be taken about the use of the latter term. First, transactions for VAT purposes do not need to be contracts as such. ${ }^{64}$ Secondly, the VAT system does not generally use nonfiscal concepts or non-fiscal ways of understanding the effect of transactions. For VAT purposes, 'transactions' are best regarded as fiscal events that have particular characteristics that enable them to be placed somewhere in the VAT

61 VAT Directive Art. 183

62 See para. 1.02 above.

63 E.g., Staatsecretaris van Financien v Hong Kong Trade Development Council (above) para. 10 of the judgment.

64 Apart from the fact that a transaction need not be a contract, the EU VAT legislation is not based upon domestic concepts of what a transaction is or what it entails: cf. Staatsecretaris van Financien $v$ Shipping and Forwarding Enterprise Safe BV (C-320/88) [1990] E.C.R. I-285 (a supply of goods, for VAT purposes, is not identified by reference to domestic rules relating to the transfer of ownership in goods); Town and County Factors Ltd v Commissioners of Customs and Excise (C-498/99) [2002] E.C.R. I-7173 (supply subject to VAT even if not based upon an enforceable contract under domestic law); Kittel $v$ Belgium (above) para. 52 of the judgment (transaction subject to VAT even if non-existent as a matter of civil law). 
system and given the appropriate tax treatment. The most important characteristic is that, by reason of the transaction, something moves from one person to another. Hence, the terms 'transaction' and 'supply' are often used interchangeably. Four types of transactions or supplies can be identified in the VAT system:

(i) taxable transactions;

(ii) exempt transactions;

(iii) exempt transactions with refund (or deduction) of the tax paid, also known as zero-rated transactions; and

(iv) non-supplies.

Each will be considered in turn.

\section{(a) Taxable transactions}

In the EU legislation, 'taxable transactions' are, strictly speaking, transactions that fall within the scope of VAT and that, accordingly, are capable of being subject to a charge to tax. Express provision is required to relieve a taxable transaction from the charge to tax. Therefore, by ellipsis, a 'taxable transaction' can be said to be a taxed transaction (in the absence of express provision otherwise). Save where there is an express provision in the EU legislation otherwise (such as where a taxable transaction is classified as exempt), the status of a transaction as a taxable (or taxed) transaction brings in its train both the obligation to charge tax and the concomitant right to deduct input tax. ${ }^{65}$

\section{(b) Exempt transactions}

Where a supply of goods or services falls within the scope of VAT, it is subject to tax unless exempt from the charge to tax by express provision. ${ }^{66}$ Exemption means that there is no charge to tax on the supply. Hence, the supplier cannot charge VAT to his purchaser. The absence of a charge to tax carries with it the inability, on the part of the supplier, to deduct input tax incurred in respect of inputs used for the making of the exempt supply (in the absence of express provision otherwise). Thus, the practical effect of exemption is to end the VAT chain with the person who makes the exempt supply. For VAT purposes, that person is the final consumer at the end of the chain of transactions. In that sense, exempt transactions are not true exemptions from VAT because VAT is still borne by someone (the person who makes the

65 By the nature of the VAT system, the Member States do not have an autonomous right to withhold the right to deduct input tax in respect of a taxable transaction.

66 Hence, using the terminology of the EU legislation, an exempt supply is a species of taxable supply. 
exempt supply). ${ }^{67}$ The practical effect of exemption is rather to prevent the incidence of VAT from going above the amount of VAT incurred by the maker of the exempt supply: that person would normally be expected to pass on the burden of the tax to his purchaser (because the burden cannot otherwise be removed through the deduction mechanism) but cannot increase it since the supply made by him is not taxed. Exemptions may be justified by various reasons, such as social or economic policy considerations or a perceived difficulty in applying VAT to particular types of transaction. ${ }^{68}$

\section{(c) Exemption with deductibility (or refund) of tax or zero rating}

1.18 Certain specified transactions or types of transactions are known as 'exemptions with deductibility of the VAT paid at the preceding stage' 69 or as 'zero rated' supplies. ${ }^{70}$ The terms are equivalent. ${ }^{71}$ Technically, however, there is a difference between them. A transaction that is exempt with deductibility of the VAT paid at the preceding stage is, strictly speaking, one that is exempt from VAT at the retail stage - the point of supply to the final consumer. In contrast to other types of exempt transaction, the supplier at the retail stage is entitled to deduct the VAT incurred at the preceding stage, that is, the VAT incurred in respect of the inputs used for the making of the exempt retail supply. No other person at any earlier stage in the chain is entitled to exempt a supply in the chain and deduct input tax. Historically, in the UK legislation implementing the EU system, that result was achieved by the zero rating of supplies of specified goods or services: the supply was classified as a taxable supply but the rate of tax was zero and, accordingly, any input tax incurred in respect of inputs used in the making of the supply was recoverable. The UK zero-rating technique applied to all transactions in the chain that satisfied the

67 The VAT incurred by the maker of an exempt supply in respect of the inputs acquired by him for the purpose of making the exempt supply is occasionally referred to as 'hidden' VAT because it is effectively recuperated (if at all) by the maker of the exempt supplier in the form of an increase in the price paid by the purchaser from the exempt supplier rather than in the form of a charge to VAT.

68 E.g., Blasi v Finanzamt Munchen I (C-346/95) [1998] E.C.R. I-481, per Advocate General Jacobs (para. 15 p. 487-difficulties in applying VAT to supplies of land); Abbey National plc $v$ Commissioners of Customs and Excise (C-169/04) [2006] E.C.R. I-4027, para. 62 of the judgment (social purpose of the exemption of management services for special investment funds). See further Ch. 10.

69 E.g., the VAT Directive Art. 110. The predecessor to Art. 110 (the Sixth VAT Directive Art. 28(2)) referred to 'exemptions with refund of the tax paid at the preceding stage'. The phraseology of the VAT Directive is technically more accurate in the sense that 'deductibility' refers generally to the offsetting of input tax against output tax. That process can lead either to a reduced payment of VAT by a taxable person to the tax authorities or to a payment from the taxable authorities (commonly described as a 'refund'). Hence, the phrase 'exemption with refund' is in a technical sense narrower, and less accurate, than the phrase 'exemption with deductibility'.

70 The expression 'zero rated' was favoured in UK and Irish legislation.

71 See Commission v United Kingdom (416/85) [1988] E.C.R. 3148 para. 10 of the judgment, where the two were considered by the Commission and by the ECJ as being equivalent. 
conditions for zero-rating, not just supplies at the retail stage. ${ }^{72}$ Exemptions with deductibility (or zero-rated transactions) are true exemptions from VAT because all the VAT is stripped out of the transaction chain. Exemptions with deductibility are not quite the same as situations in which an exempt transaction nonetheless gives rise to the deduction of input tax, although the two appear at first sight to be of the same nature. The latter appear in the VAT system because they perform a specific function in the system. ${ }^{73}$ Exemptions with deductibility appear, for the most part, as historical anomalies that reflect domestic social or economic policy considerations and are not intended to be integral features of the VAT system. ${ }^{74}$

\section{(d) Non-supplies}

Certain activities, transactions or supplies fall outside the scope of VAT. ${ }^{75}$ It is

not that they are exempt from VAT: exemption presupposes that, in the absence of the exempting provision, the exempt transaction or supply would be taxed. Instead, they do not in principle feature in the operation of the tax. However, some care needs to be taken when dealing with such phenomena because it does not always follow, from the fact that they do not feature in the operation of the tax, that they are completely irrelevant or can be ignored entirely or, as is sometimes thought, that their existence can be discounted. Generally speaking, activities, transactions or supplies falling outside the scope of the tax are disregarded (or are fiscal non-events, occasionally referred to as 'non-supplies') so far as the charge to tax is concerned but have to be taken

72 See ibid., para. 4 of the Advocate General's Opinion (p. 3139).

73 E.g., the VAT Directive Arts 138(1) and 169(b), which preserve the deduction of input tax for intraCommunity transactions, which are exempt.

74 That raises an interesting question about the role played by fiscal policy in the harmonised system. The purist view is that, as the harmonised system purports to render uniform the application of VAT (the only permitted turnover tax in the Member States) for the purposes of the common (or single) market, the common system does not, as such, feature any tax policy of the EU other than the policy of removing fiscal distortions to the creation and operation of the common (or single) market. Fiscal policy remains a matter for each Member State, not the EU, because VAT remains a domestic tax, not an EU tax. There are limits to the extent to which a Member State may introduce fiscal policy considerations into its domestic VAT legislation. Those limits are in principle set by the express terms of the harmonised system and its overall objective (domestic fiscal policy considerations are acceptable as long as they do not interfere with the establishment and operation of the common, or single, market; although, if one attribute of the single, internal market is the uniform treatment of given types of transaction in all the Member States, it seems to follow that individual Member States cannot adopt divergent fiscal policies that result in the different treatment of the same types of transaction). Although the EU does not itself have any fiscal policy (other than the establishment and operation of the common, or single, market), it can act as a forum for the co-ordination of the fiscal policies of individual Member States (to the extent that the Member States are in agreement). That summary of the position is consistent with the present state of the law (including the background to the exemptions from VAT and the arrangements for financing the EU through VAT) but other trends are from time to time discernable.

75 An example is a supply of goods or services for no consideration: see Staatsecretaris van Financien v Hong Kong Trade Development Council (above). See further Chs 3 and 5. 
into account when considering input tax deduction. Thus, publicly funded research undertaken by a university may not fall within the scope of VAT because it is not an economic, or business, activity for VAT purposes; but it does not follow that such research is to be ignored when determining the ability of the university to deduct input tax incurred in respect of inputs used for such research. ${ }^{76}$ That is due to the fact that input tax is deductible only to the extent that inputs are used for taxable (more accurately, taxed) transactions (or for other transactions that, on the basis of an express legislative provision, give rise to the deduction of input tax). The disregarding of a 'non-supply' for the purpose of the charge to tax, leads logically to the inability to deduct tax incurred in respect of inputs used for the purposes of the non-supply; it does not lead logically to the conclusion that, if the only activities, transactions or supplies that are undertaken by the taxable person concerned and that are recognised by the VAT system are taxed, all the input tax incurred by the taxable person is deductible because there is nothing else recognised by the VAT system to which the inputs can be linked. ${ }^{77}$ However, it should also be noted that not all non-supplies are treated in exactly the same way for VAT purposes. The precise way in which a non-supply is to be treated depends largely on the reasons why it is a non-supply. For example, supplies between the members of a VAT group are disregarded for VAT purposes because the members of the group form a single taxable person; but the consequences are determined by the legislative provisions dealing with VAT groups. ${ }^{78}$ The disregarding of such supplies is based essentially on the ground of simplifying the administration of the tax and it is not intended to have an incidence on the levying of the tax. Other non-supplies do have an effect on the levying of the tax.

\section{Transaction chains}

1.20 As noted above, VAT is oriented around chains of transactions leading, in principle, from production to final consumption. ${ }^{79}$ The chain is important because it provides the route by which the fiscal burden of the tax is (in

76 A more usual example is that of the exploitation of property both for the purpose of an economic activity (which is subject to VAT) and for 'private' (or non-economic) purposes (which is not subject to VAT). The latter use is ignored for the purpose of charging VAT on the use made of the property but is relevant if the owner of the property wishes to deduct input tax: e.g., Redlibs $v$ Valsts ienemumu dienests (C-263/11), 19 July 2012, para. 39.

77 See Securenta Gottinger Immobilienanlagen and Vermogensmanagement AG v Finanzamt Gottingen (C-437/06) [2008] E.C.R. I-1597 on how non-economic activities are to be taken into account in the context of input tax deduction.

78 Cf. Ampliscientifica Arl and another v Ministero dell'Economia e delle Finanze and another (C-162/07) [2008] E.C.R. I-4019, para. 19. For a fuller explanation of VAT grouping, see Ch. 4.

79 E.g., BLP Group (above) para. 30 (Advocate General Lenz). 
principle, at least) passed down to the final consumer through the operation of the deduction mechanism. It follows that chains are normally considered singly and not in groups. The chain is established by objective analysis. The basic technique used is that for the attribution of inputs to outputs when applying the deduction mechanism. ${ }^{80}$ Generally speaking, each transaction in a chain is examined separately in order to ascertain objectively what output tax is payable in respect of it and what input tax is deductible. ${ }^{81}$ However, since that exercise requires the transaction to be placed in a particular chain and related to other transactions (namely, the transactions by means of which certain supplies became inputs of the transaction under examination such that tax on those inputs is deductible), chain analysis is a frequently encountered feature of VAT. ${ }^{82}$ In that connection, it should be noted that (complex) chains of transactions can on occasion be analysed differently depending upon whether they are looked at from the perspective of the supplier or the consumer. There appears to be no rule, as yet, as to which perspective is correct or the more appropriate of the two. There is obviously an argument that, as VAT is a consumption tax, chain analysis ought to use the perspective of the consumer. ${ }^{83}$ For VAT purposes, the transaction chain ends at the stage of final consumption, when the subject-matter of the sequence of transactions is consumed by a final consumer (that is, a person other than a taxable person acting as such). In some instances (usually supplies of goods), the subjectmatter of the sequence of transactions is capable of further use, or consumption. For example, a motor car may be sold as new by a manufacturer to a dealer and thence to a final consumer. After running the car for a few years, the final consumer may sell the car to another final consumer or to a dealer in second-hand cars (or may supply it to a dealer in part-exchange for another new car). Supplies made by final consumers are ignored for VAT purposes. However, if a supply is made by a final consumer to a taxable person acting as such, and then supplied by the latter, the subject-matter of the supply is reintroduced into commercial circulation. For VAT purposes, a new chain of transactions then commences. There is no continuation of the original chain. ${ }^{84}$ Thus, in the case of the motor car sold by a taxable person (eventually) to a

80 See paras 1.12-1.14 above and Ch. 11 below.

$81 B L P$ (above) paras 19-24; Optigen v Commissioners of Customs and Excise (C-354/03, C-355/03, C-484/03) [2006] E.C.R. I-483 (Advocate General Maduro para. 29).

82 A different but related topic is the analysis of groups or sequences of transactions for the purpose of applying the EU law concept of abuse (as to which, see Ch. 2 below).

83 Auto Lease Holland BV v Bundesamt fur Finanzen (C-185/01) [2003] E.C.R. I-1317 appears to be an example of a case in which the dispute centred on which perspective was the correct one to use when analysing the chain of transactions, the ECJ opting for the consumer's perspective.

84 It should be observed that that situation arises where the subject-matter of the supply passes out of commercial circulation and later re-enters it. If, e.g., the subject-matter of the supply is rented out to a final consumer by a taxable person and, upon the expiry of the rental agreement, comes back into the possession of the taxable person and used again, it remains in commercial circulation. 
final consumer and then re-sold by the final consumer to another taxable person (a dealer) for resale, one chain of transactions ends, for VAT purposes, with the sale of the new car to the final consumer. A second chain begins once the car has been supplied, as a used car, by the final consumer to the dealer for resale. As there are two chains, in the absence of express provision, it is not possible for any VAT left in the first chain (and borne by the final consumer) to be passed on to the second chain and deducted by the dealer purchasing (for resale) the, now, used car. ${ }^{85}$ That state of affairs is regarded as theoretically producing double taxation, should the supply made by the dealer in the second chain be subject to VAT on the basis of the total consideration for the supply: part of that consideration represents, theoretically, the purchase price paid by the dealer to the final consumer, including the VAT paid by the final consumer, which the dealer is not able to deduct. ${ }^{86}$ For that reason, special provisions apply to second-hand goods. ${ }^{87}$

\section{THE PROHIBITION OF DOMESTIC TURNOVER TAXES}

1.21 Although EU law accepts the existence of tax regimes that compete with VAT (and, to that extent, accepts double taxation), the corollary to the obligation imposed on Member States of the EU to harmonise their indirect tax legislation so as to conform to the EU model of VAT is the prohibition of the use by the Member States of other forms of turnover tax. That prohibition is expressed in elaborate language. Article 401 of the VAT Directive ${ }^{88}$ provides:

Without prejudice to other provisions of Community law, this Directive shall not prevent a Member State from maintaining or introducing taxes on insurance contracts, taxes on betting and gaming, excise duties, stamp duties or, more generally, any taxes, duties or charges which cannot be characterized as turnover taxes, provided that the collection of those taxes, duties or charges does not give rise, in trade between Member States, to formalities connected with the crossing of frontiers.

That provision falls essentially into two parts.

85 E.g., Commission v Netherlands (16/84) [1985] E.C.R. 2355, paras 14-18 of the judgment; Commission v Ireland (17/84) [1985] E.C.R. 2375, paras 10-14 of the judgment. Those judgments indicate that the problem that then arises is not that the dealer who buys the second-hand car cannot deduct the VAT borne by the final consumer at the end of the first chain (that VAT is not passed on to the dealer) but that sales of second-hand items are taxed differently depending upon whether they are supplied by final consumers or by taxable persons. In later cases, a different approach was followed in relation to second-hand goods (see below).

86 E.g., Forvaltings AB Stenholmen v Riksskatteverket (above) para. 25 of the judgment. It should be observed that the double taxation in question is theoretical.

87 See Ch. 16.

88 Formerly, Sixth VAT Directive Art. 33(1). 
The first part concerns taxes on insurance contracts, taxes on betting and gaming, excise duties, stamp duties and other taxes, duties or charges that cannot be characterised as turnover taxes (referred to here as 'non-turnover taxes'). The effect of Article 401 is to preclude the operation of the harmonised VAT system from interfering with the maintenance or introduction of non-turnover taxes. The words 'maintaining or introducing' cover not only the creation and continuance of non-turnover taxes but also their general operation. Accordingly, the harmonised VAT system does not preclude double or cumulative taxation, that is, the imposition of both VAT and a non-turnover tax on the same goods or services. ${ }^{89}$ Although the immunity given to non-turnover taxes is expressed as relating to 'this Directive' and not to other VAT directives, the intention is that the immunity shall apply in relation to the harmonised VAT system in its entirety (in the absence of express provision otherwise). That follows from the fact that Directive 2006/112 (the VAT Directive) is the principal VAT directive. Other VAT directives (including those currently in force that were adopted before the adoption of the VAT Directive) now derive from the system set out in the VAT Directive and play the role of subordinate legislation by reference to the latter directive.

The immunity afforded to non-turnover taxes applies 'without prejudice to other provisions of Community law', that is, in such a way as not to impede the application of other provisions of EU law to non-turnover taxes. Such other provisions include the provisions of the TFEU (which may, in the present context, apply should a non-turnover tax interfere with the free movement of goods ${ }^{90}$ or services, ${ }^{91}$ give rise to an unlawful State aid ${ }^{92}$ or be protective or discriminative in nature ${ }^{93}$ ) and other harmonising legislation, such as the directives concerning excise duties. ${ }^{94}$ Article 401 also subjects the immunity to a condition: the collecting of non-turnover taxes must not 'give

89 E.g., Kerrutt v Fianzamt Monchengladbach-Mitte (73/85) [1986] E.C.R. 2219 para. 22 of the judgment; GIL Insurance Ltd $v$ Commissioners of Customs and Excise (C-308/01) [2004] E.C.R. I-4777 paras 43-47 of the judgment (application of a non-turnover tax to a supply exempt from VAT); Metropol Spielstatten Unternehmergesellschaft (haftungsbeschrankt) v Finanzamt Hamburg-Bergedorf, (Case C-440/12), 24 October 2013, paras 28-32; Caixa d'Estalvis i Pensions de Barcelona v Generalidad de Cataluna (C-139/12), 20 March 2014, 28; Agenzia delle Entrate - Direzione provinciale Ufficio controlli di Bolzano v Palais Kaiserkron Srl (C-549/16), 12 October 2017, para. 24; Oro Efectivo SL v Diputacion Foral de Bizkaia (C-185/18), 12 June 2019, para. 20.

90 TFEU Arts 28 and 34 apply to barriers to the movement of goods that are not covered by other Treaty provisions. Hence, fiscal measures affecting the movement of goods would normally be dealt with under the tax provisions of the TFEU (in particular Art. 110, formerly EC Treaty Art. 90): e.g., Bergandi (above) para. 33.

91 TFEU Arts 56-62 (it is conceivable that Arts 49-55, which concern the right of establishment, might also be engaged in a particular case).

92 TFEU Arts 107-109.

93 TFEU Art. 110.

94 E.g., Council Directive 92/38 ([1992] OJ L316/21). 
rise, in trade between Member States, to formalities connected with the crossing of frontiers' ${ }^{95}$ Read literally, a failure to comply with that condition would mean that the immunity from 'this Directive' would no longer apply. In order to see what effect that would have, it would then be necessary to compare the provisions of 'this Directive' (that is, the harmonised VAT regime) with the non-turnover tax in question to see if the effect of those provisions was indeed to interfere with or prevent the maintenance or introduction of the non-turnover tax in question. It is, however, unclear if that is the correct reading of Article 401. It seems more likely that non-fulfilment of the condition attached to Article 401 attracts the application of a distinct prohibition, implied in that article, to the particular feature of the nonturnover tax in question that generates a formality connected with the crossing of frontiers when the non-turnover tax is applied to trade between Member States. ${ }^{96}$

1.24 The second part of Article 401 is an implicit prohibition on the maintenance and introduction of any tax, duty or charge that can be characterised as a turnover tax. ${ }^{97}$ That prohibition can be relied upon by individuals before national courts. ${ }^{98}$ The purpose of the prohibition is to prevent the harmonised VAT system from being compromised by fiscal measures of a Member State levied on the movement of goods and services and charged on commercial transactions in a way comparable to VAT. ${ }^{99}$ Accordingly, the general test for determining whether or not a tax is a turnover tax has been stated in precisely those terms (that is, as being satisfied if the tax has the effect of compromising the functioning of the common system of VAT by levying a charge on the movement of goods and services and on commercial transactions in a way comparable to VAT). ${ }^{100}$ It should, however, be noted that, despite the apparent breadth of the prohibition, it has been stated in the case law to apply only to the cumulative application of a turnover tax to supplies and other

95 That condition was introduced by Directive 91/680 ([1991] OJ L376/1).

96 Given that the condition was imposed in the context of the amendment of the Sixth VAT Directive to take account of the abolition of fiscal frontiers between the Member States, that interpretation seems to be the more likely.

97 Bergandi (above) para. 11. Cf. Oro Efectivo (above), para. 21.

98 Dansk Denkavit and Poulsen v Skatteministeriet (C-200/90) [1992] E.C.R. I-2217 paras 16-18 of the judgment. For the reasons stated in paras 20-23 of the judgment, it is unlikely that the ECJ would be prepared in any case to limit the temporary effect of a judgment finding that a national impost was a prohibited turnover tax.

99 Rousseau Wilmot v Caisse de compensation de l'organisation autonome nationale de lindustrie et du commerce (295/84) [1985] E.C.R. 3759 para. 16 of the judgment; the Bergandi case (above) para. 9 of the judgment; N.N. Renta SA v Tribunal Económico-Administrativo Regional de Cataluna (C-151/08) [2008] E.C.R. I-164* para. 28 of the judgment (followed in Caixa d'Estalvis, above); Palais Kaiserkron (above), para. 16.

100 E.g., Giant v Gemeente Overijse (C-109/90) [1991] E.C.R. I-1385 para. 11 of the judgment; Kogaz v Zala Megyei Kozigazgatasi Hivatal Vezetoje (C-283/06 and C-312/6) [2007] E.C.R. I-8463 para. 34; Viking Motors and others v Tallinna linn and another (C-475/17), 7 August 2018, para. 36. 
transactions that are 'liable' to VAT. ${ }^{101}$ In that context, the term 'liable' does not appear to mean 'taxed' but 'within the scope of the tax'. Hence, the prohibition does not appear to apply to the application of a turnover tax to supplies or transactions that fall outside the scope of VAT ${ }^{102}$ whereas it does apply to the application of a turnover tax to supplies of goods or services that fall within the scope of VAT (including supplies that are exempt from VAT). ${ }^{103}$ The characterisation of a tax as a turnover tax for the purposes of Article 401 is a matter of EU law and, more particularly, of the true meaning of Article 401. It is not a matter of domestic law. ${ }^{104}$ Hence, the classification of a domestic tax, duty or charge as a 'turnover tax' for the purposes of domestic law does not necessarily lead to the conclusion that, for the purposes of Article 401, the tax, duty or charge is a 'turnover tax'. ${ }^{105}$

The case law shows that a tax, duty or charge can be characterised as a

turnover tax (and is therefore prohibited) by reference to its objective characteristics and not by reference to the reasons for or the circumstances surrounding its introduction, its designation under domestic law or the national legislative procedures by which it was introduced. ${ }^{106}$ Those objective characteristics must include the 'essential characteristics' of VAT, which include the following features: VAT applies generally to transactions relating to goods or services; it is proportional to the price charged by the taxable person in return for the goods and services which he has supplied; it is charged at each stage of the production and distribution process, including that of retail sale, irrespective of the number of transactions which have previously taken place; the amounts paid during the preceding stages of the process are deducted from the tax payable by a taxable person, with the result that the tax applies, at any

101 E.g., Bergandi (above) para. 11 of the judgment (repeated in Lambert v Directeur des services fiscaux de l'Orne (317/86, 48, 49, 285 and 363-367/87, 65 and 78-80/88) [1989] E.C.R. 787). Wisselink $v$ Staatsecretaris van Financien (93/88 and 94/88) [1989] E.C.R. 2671 para. 8 of the judgment, contains a dictum that can be construed as contradicting Bergandi and Lambert. The writer is of the view that the ECJ did not intend the judgment in Wisselink to contradict those cases.

102 That appears to be largely an academic point due to the approach taken by the ECJ to what is meant by a 'turnover tax' (as to which, see further below): according to that approach, a tax that was applicable only to those supplies or transactions falling entirely outside the scope of VAT would not be classified as a 'turnover tax'. On the other hand, if a tax were a turnover tax within the meaning of Art. 401 but applied both to supplies and transactions falling within the scope of VAT and to supplies and transactions falling outside the scope of VAT, it would appear that the prohibition in Art. 401 would apply only to the extent that the tax caught supplies and transactions falling within the scope of VAT but not beyond that extent.

103 GIL Insurance Ltd (above), where such a claim was made but dismissed on the ground that the disputed impost was not a turnover tax.

104 E.g., Bergandi (above) para. 13 of the judgment.

105 E.g., Tulliasiamies and Siilin (C-101/00) [2002] E.C.R. I-7487 para. 98 of the judgment: the domestic legislation actually described the tax in question as 'value added tax' but it was held not to be such a tax. The classification under domestic law may, however, be a useful indication in a complex case.

106 Wisselink (above) para. 10 of the judgment. 
given stage, only to the value added at that stage and the final burden of the tax rests ultimately on the consumer. ${ }^{107}$ In order to be a prohibited turnover tax, a national impost need not exhibit all the features of VAT. ${ }^{108}$ There is accordingly some room for argument about which features of VAT an impost must possess in order to be prohibited. Generally speaking, the cases tend to avoid being specific about the matter. The 'essential characteristics' of VAT are listed and the impost in question is then checked against those characteristics. However, it would appear that each and every one of the 'essential characteristics' of VAT must be satisfied if the impost is to be classified as a prohibited turnover tax. ${ }^{109}$

1.26 The case law shows that a tax, duty or charge cannot be characterised as a turnover tax where: it is not fiscal in nature but has been introduced specifically in order to finance social funds and is based on the activity of undertakings (or certain categories of undertakings) and calculated on the basis of total annual turnover without directly affecting the price of goods or services; ${ }^{110}$ it is levied solely on the basis that an article is placed at the disposal of the public, regardless of whether or not it is actually used, and the tax, duty or charge is not related to the revenue arising therefrom (particularly where the tax, duty or charge is payable even if the article in question is made available to the public free of charge); 111 it does not comprehend all economic transactions in the Member State concerned but applies to one product or a small range of

107 Pelzl (C-338/97, C-444/97 and C-390/97) [1999] E.C.R. I-3319 para. 21 of the judgment; Tulliasiamies (above) para. 99 of the judgment (p. 7552); Oro Efectivo (above), para. 23; Viking Motors (above), para. 39. The formulation in the GIL case (above) para. 33 of the judgment, is slightly different. As a result of the variations between the judgments, the ECJ reduced the essential characteristics to four in Banca populare di Cremona Soc Coop arl v Agenzia Entrate Ufficio Cremona (C-475/03) [2006] E.C.R. I-9373 para. 28 of the judgment: the general application of the tax; calculation of the tax due as a proportion of the price; levying of the tax at each stage of production and distribution; and deduction of the tax paid at the preceding stage (followed in: Kogaz (above) para. 37; N.N. Renta SA v Tribunal Económico-Administrativo Regional de Cataluna (C-151/08) [2008] E.C.R. I-164* [2008] E.C.R. I-165* para. 32 of the judgment; Vollkommer v Finanzamt Hannover-Land I (C-156/08) [2008] E.C.R. I-165*, para. 31 of the judgment; Dyrektor Izby Skarbowej w Bialymstoku v Profaktor Kulesza, Frankowski, Jozwiak, Orlowski sp. J (C-188/09) [2010] ECR I-7639, paras 47 (a case dismissing the argument that an administrative sanction was contrary to the prohibition); Palais Kaiserkron (above), para. 19). In relation to the last characteristic, technical differences between VAT and the domestic impost in question may not be relevant: see the Cremona case (above) para. 31.

108 E.g., Dansk Denkavit (above) paras 12-15 of the judgment and its consequence, Commission v Denmark (C-234/91) [1993] E.C.R. I-6273; Palais Kaiserkron (above), para. 17); Viking Motors (above), para. 37.

109 GIL Insurance (above) para. 34 of the judgment; Kogaz (above) para. 59 of the judgment; Palais Kaiserkron (above), para. 21 (failure to satisfy the first of the four criteria is sufficient for the impost to avoid prohibition). That means that specific attention must be paid to the formulation of the essential characteristics of VAT in the case law. Contra, the Renta case (above) para. 37, which states that a tax will be prohibited if it exhibits one or more of the characteristics of VAT.

110 Rousseau Wilmot (above) para. 16 of the judgment.

111 Bergandi (above) paras 16-20; Lambert (above). 
products; ${ }^{112}$ it applies only when a particular event occurs that is not a supply of the goods or services in question; ${ }^{113}$ the basis of assessment is not the price of the goods or services in question; ${ }^{114}$ it is not paid at each stage of the production and distribution process; ${ }^{115}$ it is not paid in respect of the value added at a particular production or distribution stage; ${ }^{116}$ it is imposed in such a way that the fiscal burden cannot with any certainty be regarded as being passed on to the final consumer. ${ }^{117} \mathrm{~A}$ tax on a tax is not likely to fall foul of the prohibition on turnover taxes if the tax on which it is charged is not a turnover tax. ${ }^{118}$ Finally, if a tax is incompatible with another tax or impost that is the subject of harmonisation (in casu, excise duties), that does not mean that it is also incompatible with VAT. ${ }^{119}$

\section{THE ORIGINS AND DEVELOPMENT OF VAT}

So far as is here relevant, the EC Treaty (now the TFEU) ${ }^{120}$ was designed to create a common or single, internal, market between the Member States of the EC (now the EU) in which goods and services could be traded under the same economic conditions and in which trade would not be distorted by fiscal considerations. In relation to trade in goods, the Treaty distinguished between taxes on the import and export of goods between Member States, which were prohibited, ${ }^{121}$ and internal taxation, which was the subject of a less stringent regime. The distinction between them was, in short, the difference between

112 Wisselink (above) para. 20 of the judgment; Giant (C-109/90) [1991] E.C.R. I-1385 para. 14 of the judgment; Beaulande (C-208/91) [1992] E.C.R. I-6709 para. 16 of the judgment; Solisnor-Estaeiros Navais (C-130/96) [1997] E.C.R. I-5053 para. 17 of the judgment; Tulliasiamies (above) para. 101 of the judgment; GIL Insurance (above) para. 35 of the judgment; Oro Efectivo (above), paras 24-26.

113 Tulliasiamies (above) para. 101 of the judgment, last sentence.

114 Ibid., para. 102 of the judgment; Cremona (above) para. 30 of the judgment; Kogaz (above) paras 39-44 of the judgment.

115 Rousseau Wilmot (above) para. 15 of the judgment; Wisselink (above) para. 20 of the judgment; Giant para. 14 of the judgment; Bozzi v Cassa Nazionale di Previdenza ed Assistenza a Favore degli Avvocati e dei Procuratori Legali (C-347/90) [1992] E.C.R. I-2947 para. 12 of the judgment; Evangelischer Krankenhausverein Wien and Wein and Co para. 49 of the judgment; Tulliasiamies (above) para. 103 of the judgment; GIL Insurance (above) para. 36 of the judgment; Palais Kaiserkron (above), para. 23; Oro Efectivo (above) paras 24-26 (which adds deductibility of the tax paid at preceding stages).

116 Wisselink (above) para. 20 of the judgment; Giant (above) para. 14 of the judgment; Tulliasiamies (above) para. 103 of the judgment, last sentence. See also Fazenda Publica v UCAL (C-347/95) [1997] E.C.R. I-4911 paras 30-37 of the judgment; Fazenda Publica v Fricarnes (C-28/96) [1997] E.C.R. I-4939 paras 34-41 of the judgment; SPAR Osterreichisches Warenhandels AG v Finanzlandes direktion fur Salzburg (C-318/96) [1998] E.C.R. I-785; GIL Insurance (above) para. 36 of the judgment; Kogaz (above) paras 45-47 of the judgment.

117 Kogaz ibid., paras 50-57 of the judgment; Viking Motors (above), paras 44-48.

118 Cf. Tulliasiamies (above) paras 104-106 of the judgment.

119 Viking Motors (above), para. 40.

120 See note 3 above.

121 By what are now TFEU Arts 28 and 30. 
taxation imposed solely by reason of the movement of goods across a frontier between the Member States and taxation taking effect within the domestic economy. ${ }^{122}$ In relation to trade in services, the Treaty provisions were rather opaque in that there was no provision dealing expressly with taxes and other charges imposed solely by reason of the movement of a service across a frontier between the Member States. ${ }^{123}$ However, it was apparent from at least Seco v $E V I, 124$ that domestic fiscal treatment affecting the cross-frontier provision of services might in certain circumstances be prohibited.

1.28 From the perspective of international trade (or trade between the members of a common market), the problem posed by internal taxation is that it is, in principle, legitimate (unlike taxation that is specifically targeted at crossfrontier transactions) but is capable of giving rise to serious distortions of trade and other difficulties. If goods or services are traded between two States and each subjects them to tax at the appropriate internal rate of tax, the aggregate tax burden will be greater than if they had been produced and consumed in only one of the States concerned. That would discourage (more likely, prevent) cross-frontier trade. If only one of the States concerned is entitled to impose a tax, which is it to be? If it is the exporting State, the importing State will be deprived of revenue. Further, if the exporting State charged a lower rate of tax than the importing State, that would give its exports an advantage over the importing State's domestic production unless the latter could impose a countervailing charge. If the exporting State did not tax its exports at all, they could be taxed by the importing State but, in principle, the tax burden imposed on them ought to be commensurate with the tax burden imposed on competing domestic products in the importing State at the same marketing stage. How is that to be calculated? If the exporting State reimbursed or remitted any tax that had been paid in respect of its exports upon their exportation, how could the importing State be sure that the amount reimbursed or remitted matched the tax burden actually suffered by the exports in the exporting State? If it exceeded the actual tax burden, the result would be a concealed export subsidy. While some of those difficulties can be resolved by the application of a prohibition (such as a prohibition on concealed export subsidies), the true solution lies in some form of co-ordinated tax treatment.

122 E.g., a tax (such as excise duty) which applies upon the first appearance of a product within the fiscal jurisdiction is internal taxation because the tax applies whether the first appearance is importation into the fiscal jurisdiction or manufacture (or first sale) within the jurisdiction. A tax that applies only upon importation and that does not apply to the corresponding internal event applies solely because of the crossing of a frontier.

123 Discriminatory taxation was, however, recognised as a form of prohibited discrimination in Title III of the General Programme for the abolition of restrictions on the freedom to provide services (OJ 1962 L/32, Eng. Sp. Ed. (2nd series) IX p. 3).

124 Seco v EVI (62 and 63/81) [1982] E.C.R. 223. 
The tax provisions of the EC Treaty, in their original form, had limited scope and were concerned with the prohibition of discriminatory and protective indirect taxation ${ }^{125}$ and with regulating cross-frontier transactions by prohibiting concealed export subsidies resulting from export rebates, ${ }^{126}$ permitting the use of average rates for border tax adjustments ${ }^{127}$ for cumulative multistage turnover taxes, ${ }^{128}$ and by prohibiting border tax adjustments for charges other than turnover taxes, excise duties and other forms of indirect taxation (that is, forms of direct taxation) unless they had received prior approval from the Council. ${ }^{129}$ Provision was made for the Commission to investigate how domestic legislation concerning turnover taxes, excise duties and other forms of indirect taxation (including border tax adjustments) could be harmonised in the interests of the common market. Any legislative measures would be adopted unanimously by the Council. ${ }^{130}$

Of the different forms of internal, indirect taxation employed in the six States that originally formed the $\mathrm{EU}$, the one that was most troublesome was the cumulative multi-stage turnover tax used by five of the six States. Under that form of taxation, a tax charge was imposed at each transaction stage on a tax-inclusive amount. From the perspective of the taxation of cross-frontier trade, that form of taxation posed two problems. First, it was very difficult to calculate accurately the tax burdening a product when it was about to be traded from one Member State to another. That meant that there was a very real risk that the border tax adjustment that would then have to be made would give rise to a concealed export subsidy or an excessive tax burden in the importing State. The average rates permitted by the EC Treaty did not provide a workable solution. Secondly, such a form of taxation produced a different tax burden for the same product depending solely upon the number of transactions taking place. It therefore favoured vertically integrated operators and posed a problem when applied to imports because, on their first appearance in

125 Art. 95 (now TFEU Art. 110 and previously Art. 90). Cf. Commission v Finland (C-10/08) [2009] E.C.R. I-39*.

126 Art. 96 (now TFEU Art. 111 and previously Art. 91).

127 Border tax adjustments could take the form of the remission or repayment of tax paid in a Member State upon the export of the products concerned to another Member State (in which case, if the remission or repayment was for an amount exceeding the tax actually charged and paid in the exporting State, the adjustment would amount to a concealed export subsidy) or a countervailing charge imposed in the importing State designed to bring the tax burden suffered by the imported product up to the level prevailing in the importing State for domestic products (in which case, if the countervailing charge were too high, imported products would be penalised).

128 Art. 97 (now repealed).

129 Art. 98 (now TFEU Art. 112 and previously Art. 92).

130 Art. 99 (now, in amended form, TFEU Art. 113 and previously Art. 93). The early history of VAT is covered in detail by some of the major commentators: see, e.g., Terra and Kajus, Ch. 9; Easson, Taxation in the European Community (Athlone, 1993) Ch. 3; Gormley in Law of the European Union, ed. Vaughan and Robertson (Richmond, 2005) s.30, Ch. 3. 
a fiscal jurisdiction, imports are ex hypothesi at a more advanced marketing stage than domestic products upon their first appearance within the same jurisdiction.

1.31 After considering possible alternative solutions, it was concluded that the VAT system offered the best way forward. The system then developed in broadly three phases, with a fourth phase now on the way.

1.32 The outlines of the VAT system were set out in the First VAT Directive, which was supplemented by more detailed provisions in the Second VAT Directive. Both Directives were to be implemented by the Member States by January 1, 1970. ${ }^{131}$ The First and Second VAT Directives did not codify the VAT system but left many things, such as the rates of tax and, to some extent, the exemptions from tax, to the Member States. The First and Second VAT Directives were supplemented by a directive on the exemption from turnover tax of goods contained in the personal luggage of international travellers. ${ }^{132}$

1.33 The next phase in the evolution of the VAT system came with the Sixth VAT Directive. ${ }^{133}$ The Sixth Directive, which was to be implemented by the Member States by January 1, 1978,134 introduced a more invasive degree of harmonisation, cutting down further on the discretion of the Member States. The mainspring for the Sixth Directive was the desire to harmonise the tax base of the VAT system. That resulted from a decision made in 1970 that the EC's budget would be financed in part through the VAT system. ${ }^{135}$ That decision was not intended to transform VAT into a tax imposed (in part) by the $\mathrm{EC} \mathrm{(or} \mathrm{EU)} \mathrm{itself} \mathrm{or} \mathrm{to} \mathrm{make} \mathrm{the} \mathrm{EC}$ (or $\mathrm{EU}$ ) a creditor in relation to any

131 The Third, Fourth and Fifth VAT Directives (Directives 69/463, 71/401 and 72/250, [1969] OJ L320/34, [1971] OJ L283/41 and [1972] OJ L162/18, respectively) were concerned essentially with altering the dates for the implementation of VAT in Belgium and Italy. In this summary of legislative developments, the large number of Council Implementing Decisions authorising different Member States to introduce derogations from the VAT Directive have not been included.

132 Directive 69/169 [1969] OJ L133/6.

133 At that stage in the history of the EC, it was commonplace to give harmonising directives a title that included their number in the envisaged programme of directives (such as the First, Second, Third, and so forth, VAT Directives). However, not all proposed directives were adopted in the same order in which they were proposed and entitled. e.g., the Eighteenth VAT Directive (Directive 89/465, [1989] OJ L226/21) was adopted four years after the Seventeenth VAT Directive (Directive 85/362, [1985] OJ L192/20) and, in between, the Twenty-First Directive (Directive 86/247, [1986] OJ L164/26) and the Thirteenth Directive (Directive 86/560, [1986] OJ L326/40) were adopted (in that order). The practice of entitling directives in that way was therefore discontinued.

134 See Art. 1. The Ninth VAT Directive (Directive 78/583, [1978] OJ L194/16) postponed the implementation date for several Member States. The Fifteenth and Twenty-first VAT Directives (Directives 83/648 and 86/247 [1983] OJ L360/49 and [1986] OJ L164/26, respectively) were concerned with the date for the introduction of VAT in Greece. The Eleventh VAT Directive (Directive 80/368, [1980] OJ L90/41) excluded the French overseas departments from the scope of VAT.

135 Council Decision No.70/243 ([1970] OJ L94/19, Eng. Sp. Ed. 1970(1) p. 224) since repealed and replaced. 
part of the tax debt incurred by taxable persons. Instead, the decision made in 1970 was that each Member State should pay to the EC an amount of money calculated by applying a percentage figure to the VAT assessment base (not to the amount of VAT raised by that State). Hence, there is no direct legal connection between the obligation of taxable persons to account for VAT to the tax authorities of the Member States and the entitlement of the EU to receive a sum of money from the Member States. That way of funding the EU would not have worked fairly as between the Member States under the VAT regime created by the First and Second VAT Directives because there were too many variations between the Member States affecting the VAT assessment base. Accordingly, it was necessary to harmonise the VAT assessment base as much as was possible at that stage. ${ }^{136}$ It should be noted that the degree of harmonisation effected by the Sixth Directive went beyond that which was strictly required for fiscal reasons or for the purpose of achieving the objectives of harmonisation as set out in what was, at the time, the EC Treaty, since the purpose served was non-fiscal (namely, to resolve a particular problem concerning the financing of the EC, as it then was). Shortly after the adoption of the Sixth VAT Directive, two directives on mutual assistance between the Member States were adopted. ${ }^{137}$ The Eighth VAT Directive (in 1979) and the Thirteenth VAT Directive (in 1986) dealt with the refund of VAT to traders not established in the territory of the country in which it was levied and to traders established outside the EU.138 Other directives dealt with exemptions from VAT on the importation of goods, ${ }^{139}$ the hiring of movable tangible property, ${ }^{140}$ a derogation benefiting German farmers, ${ }^{141}$ VAT on the temporary importation of goods, ${ }^{142}$ and the abolition of certain derogations. ${ }^{143}$

136 It falls outside the scope of this work to consider in detail the financing of the EU. It suffices to point out (by way of example) that, at the time of first writing this chapter, the VAT component of the EU's own resources was based on a maximum rate of call of 0.30 per cent of the VAT assessment base (the latter as capped at 50 per cent of GNP): see Council Decision 2007/436 ([2007] OJ L163/17). The VAT assessment (or resource) base was determined in accordance with a rather complicated method of calculation set out in Council Regulation No.1553/89 ([1989] OJ L155/9). Since then, the own resources legislation has changed but the basic system remains the same.

137 Directives 79/1070 and 79/1071 ([1979] OJ L331/8 and 10). The latter amended an earlier directive on mutual assistance, Directive 76/308 ([1976] OJ L73/18), extending its scope to cover VAT.

138 Directives 79/1072 and 86/560 ([1979] OJ L331/11 and [1986] OJ L326/40, respectively). The former was repealed with effect from January 1, 2010 by Directive 2008/9 ([2008] OJ L44/23).

139 Directive 83/181 ([1983] OJ L105/38), amended by Directives 85/346, 88/331 and 89/219 ([1985] OJ L183/21, [1988] OJ L151/79 and [1989] OJ L92/13, respectively).

140 The Tenth VAT Directive (Directive 84/386, [1984] OJ L208/58).

141 The Twentieth VAT Directive (Directive 85/361, [1985] OJ L192/18).

142 The Seventeenth VAT Directive (Directive 85/362, [1985] OJ L192/20), amended by Directive 90/237 ([1990] OJ L133/41).

143 The Eighteenth VAT Directive (Directive 89/465, [1989] OJ L226/21). 
1.34 The third stage in the development of the VAT system was initiated in the 1990s with the move towards the completion of what was then known as the 'single' or 'internal' or 'single, internal' market. ${ }^{144}$ The principal feature of that concept was the removal of frontier controls on trade between the Member States of the EU: the idea was that persons, goods and services should move freely across the political frontiers dividing one Member State from another without being subject to physical inspections or checks, leading to the complete removal of frontier posts. Frontier posts were then in existence in part for the purpose of ensuring that goods sent from one Member State to another were subject to VAT and excise duties upon entry into the country of importation. In the course of the late 1980s, various proposals were made for altering the different systems of VAT and excise duties with a view to removing the need for fiscal controls at the frontiers of the Member States. Those moves bore fruit in the adoption of Directive 91/680. ${ }^{145}$ That Directive amended the Sixth VAT Directive by inserting a new system for dealing with intra-Community transactions in goods and services. The new system was intended to be in place for a transitional phase running from January 1, 1993 (the date of the abolition of fiscal controls at internal EU frontiers-that is, the frontiers between the Member States) to December 31, 1996. On the latter date, the definitive system for dealing with intra-Community transactions was to be introduced.

1.35 In a nutshell, the system replaced by Directive 91/680 involved the remission of VAT on exports from one Member State to another and the imposition of VAT by the importing State. That system also incorporated various tax exemptions and duty-free allowances for intra-Community transactions. The transitional arrangements introduced by Directive 91/680 left that system in place so far as transactions involving third countries were concerned. In relation to intra-Community transactions, the concepts of 'export' and 'import' were abolished as being redolent of the state of affairs preceding the 'single' market and their use was reserved to transactions involving third countries. However, their abolition did not lead to the creation of a single fiscal jurisdiction matching the single market. Instead, they were replaced by circumlocutory language, in particular, the phrase intra-Community acquisition'. The plan of the transitional arrangements for intra-Community

144 The EC Treaty had originally envisaged the completion of the 'common market' in stages by December 31, 1969. That date was not met. In the course of the 1980s, the Commission relaunched the process with the goal of completing it by 1992. It is entirely possible that the replacement of the phrase 'common market' by 'internal market' or 'single market' and cognate phrases at that time reflected a desire not to be reminded of the failure to meet the original date and the failure to do anything much about it for more than a decade thereafter.

145 Directive 91/680 ([1991] OJ L376/1). 
transactions was in essence that such transactions would be taxed in the Member State of destination. Accordingly, the sending of goods or services from one Member State to another would be exempt with refund of the tax previously paid in the Member State of origin (that is, zero-rated) but subject to 'acquisition' VAT in the Member State of destination. The definitive system for intra-Community transactions, intended to be brought into effect after December 31, 1996, was to be based on the principle of the taxation of goods and services in the Member State of origin, without prejudice to the principle that, in the case of transactions between taxable persons, tax revenues from the imposition of tax at the final consumption stage should accrue to the benefit of the Member State in which final consumption took place. ${ }^{146}$ The transitional system, and progress towards the definitive system, required some further harmonisation and simplification of the common system of VAT. In the event, although the further harmonisation and simplification took place, the definitive system was not adopted and, at the time of writing, intraCommunity transactions remain governed by the transitional system.

Following Directive 91/680, further legislation was adopted concerning, among other things: amendments necessary to deal with the accession of new Member States; ${ }^{147}$ rates of tax; ${ }^{148}$ the simplification of the system; ${ }^{149}$ mutual assistance between the tax authorities of the Member States; ${ }^{150}$ VAT on telecommunications services; ${ }^{151}$ the determination of the person liable for late payment of VAT; ${ }^{152}$ VAT invoices; ${ }^{153}$ VAT on services supplied by electronic means; ${ }^{154}$ the application of VAT to supplies of gas and electricity; ${ }^{155}$ procedures approving national measures derogating from the harmonised system and the making by the Council of rules for implementing the

146 A general summary of the position can be gleaned from the preamble to Directive 91/680 ([1991] OJ L376/1) but that does not do full justice to a very complicated and controversial situation. For a more detailed account, see, e.g., Terra and Kajus, $A$ Guide to the European VAT Directives. Directive 2004/66 ([2004] OJ L168/35); Directive 2006/98 ([2006] OJ L363/129).

148 Directive 92/77 ([1992] OJ L316/1); Directive 1999/49 ([1999] OJ L139/27); Directive 2000/17 ([2000] OJ L84/24), a temporary measure benefiting Austria and Portugal; Directive 2001/4 ([2000] OJ L22/17); Directive 2002/93 ([2002] OJ L331/27) and Directive 2004/15 ([2004] OJ L52/61) on reduced rates for labour-intensive services; Directive 2005/92 ([2005] OJ L345/19).

149 Directive 92/111 ([1992] OJ L384/47); Directive 95/7 ([1995] OJ L102/18).

150 Regulation No.218/92 ([1992] OJ L24/1), later replaced by Regulation No.1798/2003 ([2003] OJ L264/1); Directive 2003/93 ([2003] OJ L 264/23), which amended Directive 77/799.

151 Directive 1999/59 ([1999] OJ L162/63).

152 Directive 2000/65 ([2000] OJ L269/44).

153 Directive 2001/115 ([2002] OJ L15/24).

154 Directive 2002/38 ([2002] OJ L128/41).

155 Directive 2003/92 ([2003] OJ L269/8). 
harmonised system; ${ }^{156}$ specific rules on the application of the harmonised system in particular situations; ${ }^{157}$ and measures dealing with avoidance and evasion. ${ }^{158}$

1.37 In 2006, the First and Sixth VAT Directives, as amended over the years, were recast in the form of what is now commonly called 'the VAT Directive' and repealed. ${ }^{159}$ The purpose of doing so was to present the provisions of the Sixth Directive and its many amendments in a clear and rational manner. The First Directive was included in the VAT Directive for essentially the same reason. Recasting the First and Sixth Directives involved changes in the wording of their provisions as well as their structure. However, apart from a small number of substantive amendments that were considered to be inherent in the recasting exercise, there was no intention to make any substantive change in the provisions of the First and Sixth Directives, as already amended. ${ }^{160}$

1.38 From 2006 to 2008 there were only relatively minor amendments to the VAT Directive. ${ }^{161}$ But then a new phase in the development of VAT was initiated with the implementation of what was known as 'the VAT Package', a modernisation and simplification of the application of VAT to supplies of services that had been heralded before the adoption of the VAT Directive. The main change consisted of a group of measures primarily designed to secure the taxation of services in the place of consumption. In that, the fourth phase of the development of VAT in the EU, which ran from 2008 to 2010, attention also shifted to the need to combat fraud, the desirability of reducing the costs of administering VAT and the need to revise the application of VAT to financial services. In the fourth phase, more extensive amendments to the VAT system were made concerning the place of supply of services, ${ }^{162}$ revised rules for the refund of VAT to taxable persons not established in the Member State of refund but established in another Member State, ${ }^{163}$ measures to

156 Directive 2004/7 ([2004] OJ L27/44).

157 Regulation No.1777/2005 ([2005] OJ L288/1), repealed and replaced by Regulation No. 282/2011 ([2011] OJ L77/1), which has since been considerably amended. The purpose of that regulation and its successor was to clarify certain concepts and provisions of (now) the VAT Directive and it may therefore be taken into account even in relation to situations coming into existence before the adoption of the regulation: Welmory sp. z o.o. v Dyrektor Izby Skarbowej w Gdansku (C-605/12), 16 October 2014, paras 45-46.

158 Directive 2006/69 ([2006] OJ L221/9).

159 Directive 2006/112 ([2006] OJ L347/1). A corrigendum was published in [2007] OJ L335/60.

160 The VAT Directive recitals 1-3 of the preamble.

161 See Directives 2006/138 ([2006] OJ L384/92-radio and television broadcasting services and certain electronically supplied services) and 2007/75 ([2007] OJ L346/13—certain derogations concerning rates of $\operatorname{tax})$.

162 Directive 2008/8 ([2008] OJ L44/11).

163 Directive 2008/9 ([2008] OJ L44/23). 
combat tax evasion and fraud, ${ }^{164}$ reduced rates, ${ }^{165}$ the exemption of imports of small consignments of negligible value, ${ }^{166}$ miscellaneous matters, ${ }^{167}$ invoicing ${ }^{168}$ and the duration of the obligation to respect a minimum standard rate. ${ }^{169}$ Progress then paused until 2013, when three further directives were adopted dealing with combating fraud ${ }^{170}$ and a minor change to the territorial scope of the VAT system. ${ }^{171}$ Another three year pause followed. Between 2016 and 2018, the duration of the obligation to respect a minimum standard rate was again modified; ${ }^{172}$ the treatment of vouchers was clarified; ${ }^{173}$ certain obligations affecting supplies of services and distance sale of goods were modified; ${ }^{174}$ further action was taken to combat fraud; ${ }^{175}$ the rates of VAT applicable to books, newspapers and periodicals were modified; ${ }^{176}$ certain rules affecting inter-State trade were harmonised and simplified;177 and provision was made for a temporary generalised reverse charge mechanism for supplies above a certain threshold. ${ }^{178}$ The post-2016 changes to the harmonised system involve a significant reshaping of the system. At the time of writing, a consolidated version of the VAT Directive containing the amendments made to January 1, 2020, was available on the EU's website. ${ }^{179}$

164 Directive 2008/117 ([2009] OJ L14/7) —intra-Community transactions; Directive 2009/69 ([2009] OJ L175/12)—imports; Directive 2010/23 ([2010] OJ L72(1))—reverse charge mechanism applicable to surplus susceptible to fraud. Directive 2009/47 ([2009] OJ L116/18).

166 Directive 2009/132 ([2009] OJ L292/5).

167 Directive 2009/162 ([2010] OJ L10/14).

168 Directive 2010/45 ([2010] OJ L189/1).

169 Directive 2010/88 ([2010] OJ L326/1).

170 Directive 2013/42 ([2013] OJ L201/1) - creation of a quick reaction mechanism for combating VAT fraud; Directive 2013/43 ([2013] OJ L201/4) - temporary application of the reverse charge mechanism to certain supplies of goods and services.

171 Directive 2013/61 ([2013] OJ L353/5).

172 Directive 2016/856 ([2016] OJ L142/12); Directive 2018/912 ([2018] OJ L162/1)

173 Directive 2016/1065 ([2016] OJ L177/9).

174 Directive 2017/2455 ([2017] OJ L348/7). The main provisions come into force on January 1, 2021.

175 Directive 2018/1695 ([2018] OJ L282/5) - period of application of the optional reverse charge mechanism and the Quick Reaction Mechanism.

176 Directive 2018/1713 ([2018] OJ L286/20).

177 Directive 2018/1910 ([2018] OJ L311/3) - to be implemented as from January 1, 2020.

178 Directive 2018/2057 ([2018] OJ L329/3)

179 That consolidated version is defective. For example, VAT Directive Arts 59-59b are either incomplete or missing (that appears to be the case for all consolidated versions published since January 1, 2014). 